SANTOS, André Leonardo Copetti; LUCAS, Doglas Cesar. Por uma epistemologia dos vencidos: reposicionamentos teóricos para uma responsabilidade comum universal sobre as mobilidades humanas de massa. Revista Eletrônica Direito e Política, Programa de Pós-Graduação Stricto Sensu em Ciência Jurídica da UNIVALI, Itajaí, v.13, n.3, 30 quadrimestre de 2018. Disponível em: www.univali.br/direitoepolitica - ISSN 1980-7791

\title{
POR UMA EPISTEMOLOGIA DOS VENCIDOS: REPOSICIONAMENTOS TEÓRICOS PARA UMA RESPONSABILIDADE COMUM UNIVERSAL SOBRE AS MOBILIDADES HUMANAS DE MASSA
}

\author{
FOR AN EPISTEMOLOGY OF THE LOSERS: THEORETICAL REPOSITIONINGS FOR A \\ UNIVERSAL COMMON RESPONSIBILITY FOR MASS HUMAN MOBILITIES
}

\section{André Leonardo Copetti Santos ${ }^{1}$ \\ Doglas Cesar Lucas²}

\begin{abstract}
SUMÁRIO: Introdução; 1 A vida precária pede um lugar: a imigração dando contornos ao mundo; 2 O Estado-nação, o Estado de Direito e o capitalismo como elementos centrais das razões teórica e prática sobre as migrações; 3 A insuficiência da concepção legal-nacionalista de cidadania e do discurso eurocêntrico dos direitos humanos para o enfrentamento das mobilidades de massa contemporâneas; 4 Sobre a responsabilidade comum universal pelos direitos humanos dos migrantes; 5 Esboçando uma epistemologia dos vencidos. Elementos parciais, iniciais e indicativos para uma nova visão da responsabilidade comum universal sobre os direitos humanos dos migrantes; Considerações finais; Referências das fontes citadas.
\end{abstract}

\section{RESUMO}

O presente trabalho busca estabelecer alguns pontos de reflexão sobre a necessidade de superação de um conjunto de teorizações e práticas políticas essencialmente nacionalistas, legalistas e capitalistas, bastante ineficazes no tratamento da questão das migrações, propondo sua substituição por uma ética da responsabilidade universal comum pela efetivação dos direitos humanos dos migrantes. O trabalho objetiva, primeiramente, estabelecer uma crítica a esses saberes e práticas coloniais sobre as mobilidades humanas, para, num segundo momento, propor de forma inicial e indicativa, alguns caminhos que possibilitem a construção de novos marcos teóricos libertadores e

\footnotetext{
${ }^{1}$ Pós-Doutor pela Universidade do Vale do Rio dos Sinos (UNISINOS) e pós-doutorando pela Universidade de Santiago do Chile (USACH). Possui mestrado (1999) e Doutorado (2004) em Direito pela Universidade do Vale do Rio dos Sinos e graduação em Direito pela Universidade de Cruz Alta (1988). Atualmente é professor do corpo permanente do Programa de Pós-Graduação em Direito da UNIJUÍ, IJUÍ, RS e do Programa de PósGraduação em Direito da URI, Santo Ângelo, RS. Coordenador Executivo do PPGD/URISAN. Editor da Revista Científica Direitos Culturais. Membro Externo do Conselho Editorial do Centro de Estudios en Antropología y Derecho, Posadas, Argentina. Membro fundador da Casa Warat Buenos Aires e da Editora Casa Warat. Livros e artigos publicados nas áreas de direito penal, direito constitucional, teoria do direito e ensino jurídico. Advogado criminalista. E-mail: andre.co.petti@hotmail.com

2 Possui graduação em Direito pela Universidade Regional do Noroeste do Estado do Rio Grande do Sul UNIJUÍ (1998), mestrado em Direito pela Universidade Federal de Santa Catarina (2001), Doutorado em Direito pela UNISINOS (2008) e Pós-Doutorado em Direito pela Università Degli Studi di Roma Tre (2012). É professor dos Cursos de Graduação e de Mestrado em Direito na Universidade Regional do Noroeste do Estado do Rio Grande do Sul - Unijui e professor no Curso de direito da Faculdade Cnec Santo Ângelo. Professor colaborador no mestrado e doutorado em Direito da URI - Santo Ângelo. Editor da Revista Direito em Debate, publicação do Departamento de Ciências jurídicas e Sociais da Unijui. É coordenador da Coleção Direitos Humanos e Democracia, publicada pela editora Unijui. Avaliador do MEC/INEP. Tem experiência na área de Direito, com ênfase em Filosofia do Direito, atuando principalmente nos seguintes temas: Direitos humanos, identidade, interculturalidade, desobediência civil, direito de resistência e democracia. E-mail: andre.co.petti@hotmail.com
} 
SANTOS, André Leonardo Copetti; LUCAS, Doglas Cesar. Por uma epistemologia dos vencidos: reposicionamentos teóricos para uma responsabilidade comum universal sobre as mobilidades humanas de massa. Revista Eletrônica Direito e Política, Programa de Pós-Graduação Stricto Sensu em Ciência Jurídica da UNIVALI, Itajaí, v.13, n.3, 30 quadrimestre de 2018. Disponível em: www.univali.br/direitoepolitica - ISSN 1980-7791

emancipatórios sobre as questões que envolvem mobilidades humanas de massa. $\mathrm{O}$ método de abordagem utilizado foi o dialético e o procedimento metodológico foi baseado na investigação bibliográfica. Os resultados iniciais fundados na ideia de uma responsabilidade comum universal alentam possíveis novas construções teóricas que permitam novas práticas sociais e políticas em relação aos migrantes.

Palavras-chave: migrações; epistemologia dos vencidos; responsabilidade comum universal; direitos humanos dos migrantes.

\section{ABSTRACT}

The present work seeks to establish some points of reflection on the need to overcome a set of essentially nationalist, legalistic and capitalist theorizations and political practices that are absolutely ineffective in the treatment of the issue of migration, proposing its replacement by an ethics of common universal responsibility for effectiveness human rights of migrants. The work objective, firstly, to establish a criticism of these colonial knowledge and practices on human mobility, in order to propose, in a second moment, in an initial and indicative way, some ways of building new theoretical frameworks based on a notion of universal common responsibility on issues involving mass human mobility. The method of approach used was the dialectic and the methodological procedure was based on the bibliographical research. The initial results based on the idea of a universal common responsibility encourage possible new theoretical constructions that allow new social and liberator political practices towards the migrants.

Keywords: Migrations; Epistemology of the losers; Universal common responsibility; Human rights of migrants.

\section{INTRODUÇÃO}

A população e suas mobilidades como um problema específico de governabilidade, apesar de situar-se orgânica e sistematicamente como uma pauta política moderna, mais especificamente ligada ao Estado-nação, já havia sido apresentada na antiguidade em algumas construções discursivas, tais como na "A República" de Platão, em seu fragmento $423^{3}$, ou na "Política" de Aristóteles ${ }^{4}$, que em seu Livro IV constrói uma "Teoria Geral da Cidade Perfeita", dedicando especial atenção ao tema da população no parágrafo $3^{\circ}$ deste capítulo, ao tratar da extensão que deve ter uma cidade-estado.

O discurso bíblico também não desconhece a mobilidade humana e a trata quase como uma saga sem fim, seja de modo objetivo e temporal, seja de modo transcendente. Em Êxodo, 23: 9, por exemplo, está clara a recomendação de que "Também não oprimirás o estrangeiro; pois vós conheceis o coração do estrangeiro, pois fostes estrangeiros na terra do Egito".

Mesmo na Europa ruralizada da Alta Idade Média, que favoreceu a economia baseada na agricultura, onde evidenciou-se um insignificante uso de moedas, a formação de feudos e

\footnotetext{
${ }^{3}$ PLATÃO. A República. 8. ed. Lisboa: Fundação CalousteGulbenkian, 1996.

${ }^{4}$ ARISTÓTELES. Política. São Paulo: Martin Claret, 2002, p. 125.
} 
SANTOS, André Leonardo Copetti; LUCAS, Doglas Cesar. Por uma epistemologia dos vencidos: reposicionamentos teóricos para uma responsabilidade comum universal sobre as mobilidades humanas de massa. Revista Eletrônica Direito e Política, Programa de Pós-Graduação Stricto Sensu em Ciência Jurídica da UNIVALI, Itajaí, v.13, n.3, 30 quadrimestre de 2018. Disponível em: www.univali.br/direitoepolitica - ISSN 1980-7791

poucos contatos comerciais externos, a mobilidade humana, reduzida em todos os sentidos, desafiava os vínculos com a terra. O renascimento da vida urbana, cultural e comercial que caracterizam a Europa a partir do século $X$, promoveu um significativo crescimento demográfico da Europa ocidental e provocou um desiquilíbrio entre oferta e demanda por alimentos. Para enfrentar a escassez de recursos, grupos foram marginalizados no interior das cidades e a necessidade de expandir territórios se constitui numa alternativa. As cruzadas se inserem nesse processo. Nesse, como em outros períodos, o homem engenhou soluções pela utilização de mecanismos de poder voltados para dentro e para fora das comunidades que produziram por vezes mais empatia e outras vezes menos empatia em relação ao sujeito vindo de fora. É nesse contexto que surge a teorização de Botero sobre a questão populacional ${ }^{5}$.

Numa época marcada pelo aumento da população e do aumento dos padrões de vida e crescimento econômico, o pessimismo de Botero sobre o crescimento da população era pouco provável a cair em ouvidos amigáveis. As teses mecanicistas de Botero foram fortemente criticadas. Teóricos dos séculos XVII e XVIII, como, por exemplo, Montesquieu, associaram, contrariando toda razão boteriana, o crescimento populacional à ideia de prosperidade e crescimento econômico. No Livro Vigésimo Terceiro do "Espírito das Leis", Montesquieu desenvolve um tópico denominado "Das leis em sua relação com o número de habitantes", tendo vários capítulos nele (XIV, XVI, XXIV, XXV, XXVI, XXVII, XXVIII e XXXI) que dão conta de uma especial atenção do autor para o problema da gestão da população em associação com a questão do desenvolvimento dos Estados ${ }^{6}$. Mas nos primórdios da Idade Moderna, provavelmente o ensaio mais impactante sobre a questão populacional seja de Malthus, cuja perspectiva em seu "Um Ensaio sobre o Princípio da População"7 é a de que a população não é indefinidamente um recurso, podendo converter-se em um não-recurso. Para isto, a demografia, disciplina tipicamente moderna passou a ser um instrumento de poder que se constituiu a partir do século XVIII, como a finalidade de fazer a contabilidade de pessoas e coisas. É o controle pelo número, pela posse de signos.

Nos dias atuais, a globalização, em todas as suas facetas, tornou ainda mais evidente as trocas e os processos de interação humana, em sua dimensão positiva e negativa, criando condições para uma produção científica sobre as mobilidades humanas sem

\footnotetext{
${ }^{5}$ BOTERO, Giovani. On the Cause of the Greatness of Cities. Toronto: University of Toronto Press, 2012.

${ }^{6}$ MONTESQUIEU. O Espírito das Leis. São Paulo, Martins Fontes, 1996, p. 458.
}

7 MALTHUS, Thomas. An Essayon the Principle of Population. Adelaide: The University of Adelaide Libray. Disponível em: http://ebooks.adelaide.edu.au/m/malthus/thomas/m26p/index.html_. Acesso em: 20 jun. 2014. 
SANTOS, André Leonardo Copetti; LUCAS, Doglas Cesar. Por uma epistemologia dos vencidos: reposicionamentos teóricos para uma responsabilidade comum universal sobre as mobilidades humanas de massa. Revista Eletrônica Direito e Política, Programa de Pós-Graduação Stricto Sensu em Ciência Jurídica da UNIVALI, Itajaí, v.13, n.3, 30 quadrimestre de 2018. Disponível em: www.univali.br/direitoepolitica - ISSN 1980-7791

precedentes na história. Entretanto, essa reflexão sobre os processos migratórios tem sido fundamentalmente produzida desde uma localização bem definida - ocidental e colonial -, indicando uma ação hermenêutica pela qual o observador se "situa" (comprometidamente) em algum "lugar" sócio-histórico como sujeito de enunciação de um discurso, e por isso é o lugar "desde onde" são feitas as perguntas problemáticas (das quais se tem autoconsciência crítica ou não) que constituem os pressupostos de uma epistemeepocal. Essa episteme sobre as mobilidades humanas, que invariavelmente se projeta nas decisões políticas tomadas pelos governantes, tem sido uma episteme dos vencedores e não dos vencidos; tem sido uma episteme dos sedentários, e não dos nômades; uma episteme nacionalista e capitalista e não universalista/cosmopolita e solidária.

O presente trabalho busca refletir, de modo parcial e indicativo, sobre a necessidade de superação desse conjunto de teorizações e práticas políticas essencialmente nacionalistas, legalistas e capitalistas, com alto grau de ineficácia no tratamento da questão das migrações, propondo sua substituição por uma ética da responsabilidade universal comum pela efetivação dos direitos humanos dos migrantes. Para isso, como condição prévia, é necessário que refaçamos nossos conjuntos de saberes sobre as mobilidades humanas, reposicionando nos e, consequentemente, deslocando nosso olhar desde a perspectiva dos vencidos, ou seja, dos migrantes.

Para o desenvolvimento da presente pesquisa que ora relatamos, foi utilizado o método dialético. O mecanismo metodológico aqui utilizado acasala os dois temas centrais do pensamento hegeliano: por um lado, as "três idades" da evolução vital (nascimento, desenvolvimento e declínio) e, por outro, a ascensão da humanidade, fazendo que o túmulo de uma instituição seja o berço de outra maior. Temos, desse modo, que toda existência, toda ideia, toda instituição seguem uma démarche em três etapas, segundo a famosa tríade: tese, antítese e síntese, ou mais precisamente: afirmação, negação e negação da negação. Toda existência, toda ideia, toda instituição começa por se afirmar: é o nascimento da tese, que aqui se expressa por um conhecimento acerca das migrações produzido fundamentalmente sobre bases nacionalistas, legalistas e capitalistas. Posteriormente, suscita uma oposição e secreta o seu contrário: é a antítese, representada em termos de saberes sobre migrações por uma epistemegarantista de direitos humanos, mas com uma produção localizada nos países do norte do planeta. Por fim, é do conflito da potência desses dois sentidos que poderá emergir um novo sentido (síntese) de um conhecimento sobre as migrações que permita novas ações a partir de uma concepção de responsabilidade comum universal pela efetivação dos direitos dos 
SANTOS, André Leonardo Copetti; LUCAS, Doglas Cesar. Por uma epistemologia dos vencidos: reposicionamentos teóricos para uma responsabilidade comum universal sobre as mobilidades humanas de massa. Revista Eletrônica Direito e Política, Programa de Pós-Graduação Stricto Sensu em Ciência Jurídica da UNIVALI, Itajaí, v.13, n.3, 30 quadrimestre de 2018. Disponível em: www.univali.br/direitoepolitica - ISSN 1980-7791

migrantes, com uma leitura descolonizadora e libertadora dos direitos humanos no que toca aos migrantes.

\section{A VIDA PRECÁRIA PEDE UM LUgAR: A IMIGRAÇÃO DANDO CONTORNOS AO MUNDO}

Os deslocamentos humanos, forçados ou não, podem nos dar evidências substanciais de como a humanidade traçou seus caminhos até os dias de hoje. Os contornos do mundo, de suas narrativas, institucionalidades, violências, foram e continuam sendo forjados pelas possibilidades da movimentação humana, pelos limites impostos à sua mobilidade e pelo controle social (sobretudo a partir da modernidade) de sua contingência. Os grandes processos de mobilidade humana estão ligados a questões políticas, étnicas, religiosas, guerras, catástrofes ambientais, fome etc., que provocaram ao longo da história uma reconfiguração permanente da geografia do poder e da vida em todas as suas formas de representações. O nômade tinha, e continua a ter, no movimento permanente a condição de possibilidade da vida em termos biológicos e biográficos. O imigrante contemporâneo precisa mover-se para não sucumbir e para manter-se vivo. É mais um apelo de preservação do que qualquer outra coisa.

O resultado dessa dinâmica nem sempre foi positivo. Afinal, muitos idiomas foram extintos juntamente com seus povos; diferenças estirpadas e outras tornadas majoritárias; negação de liberdades e muita violência institucional por parte de maiorias institucionalizadas, sobretudo através do Estado. Mestiçagem e hibridismo cultural também resultaram desse processo de encontros inesperados e nem sempre desejados com o estranho. Negros retirados forçosamente de seus familiares e de sua cultura foram escravizados e deslocados para terras desconhecidas. A violência foi a marca desse modelo de produção que colonizava o corpo do negro e sua biografia de modo incondicional.

Da mesma forma as populações originárias sofreram com o paradigma modernizador europeu, tendo que se tornar estrangeiros dentro de sua própria terra. A imigração do século 19 apresentou-se com uma alternativa para a fome e as crises do velho continente, mas significou separações dolorosas, assimilacionismos, fusões culturais e a construção de novas identidades que cobraram o custo de se negar as antigas formas de pertença. Durante e após a Segunda Grande Guerra uma das maiores diásporas contemporâneas colocou em movimento milhões de pessoas, e a reorganização dos espaços e das culturas era a condição de possibilidade para que as pessoas continuassem vivas. Os judeus, por exemplo, alvo de inúmeras perseguições ao longo da história, mais 
SANTOS, André Leonardo Copetti; LUCAS, Doglas Cesar. Por uma epistemologia dos vencidos: reposicionamentos teóricos para uma responsabilidade comum universal sobre as mobilidades humanas de massa. Revista Eletrônica Direito e Política, Programa de Pós-Graduação Stricto Sensu em Ciência Jurídica da UNIVALI, Itajaí, v.13, n.3, 30 quadrimestre de 2018. Disponível em: www.univali.br/direitoepolitica - ISSN 1980-7791

uma vez tiveram que se colocar em marcha e reconstruir sua comunidade. A imigração, em grande medida, é um ato de sobrevivência, um movimento de preservação, estando diretamente relacionado ao desejo de melhorar de vida, e em casos extremos, de proteger a própria vida. A vida, nesse caso, encontra no movimento as condições de ser, de sua permanência no mundo.

As movimentações humanas dizem muito de como a vida é percebida e de como ela define os padrões de normalidade para um indivíduo poder fazer parte ou não de uma dada comunidade. Parece que o "dentro" e o "fora" das comunidades, seja nas mais primitivas ou nas mais organizadas, continuam dando a tonalidade da mobilidade humana. Pertencer é também uma forma de negar acessos, de não pertencer a outro lugar. Construímos a pertença de modo ambivalente, inventando o estranho, o estrangeiro, o inimigo, a ameaça que vem de fora e que deve lá ser mantida, ou que está dentro e deve ser eliminada jogando-a para fora. A modernidade reforçou essa lógica do "dentro" e do "fora" e Ihe outorgou um estatuto jurídico. Mas o que fazer quando não se é bem-vindo em nenhum lugar? Mover-se? Para onde? Num mundo arbitrariamente dividido, o imigrante e o refugiado parecem não ser desejados por ninguém. Um olhar de suspeição Ihes é sempre dirigido. Ameaça, risco e medo acompanham a jornada daqueles que precisam encontrar "lá fora" um lugar para viver suas vidas.

No presente século a estranheza e o "não lugar" são categorias que ajudam a compreender o atual estágio de transformações que afetam as mobilidades humanas. Já não falamos de movimentos constitutivos de novas nações por influxos migratórios controlados e fomentados politicamente, como se deu na América Latina e nos EUA, por exemplo. O fato mais emblemático é o surgimento de grandes movimentos migratórios advindos de países em conflito ou extremamente pobres que visam a alcançar os países em melhores condições materiais de vida, os quais não estão dispostos a recebê-los ou apresentam limitações para tanto. Este é o dilema vivido pela Europa atualmente; esta é a situação vivida por uma massa de venezuelanos na América Latina. A região que iniciou o movimento de universalização dos direitos humanos vê-se desafiada duplamente: responder internamente à sua população que deseja restringir o ingresso de imigrantes e ao mesmo tempo dar conta de uma agenda de direitos humanos universais que impede tamanha discriminação de acesso.

O fortalecimento da Europa ocidental, com mais direitos e vantagens para os seus cidadãos, sem uma política clara para o seu entorno, produziu uma dupla consequência: a Europa, dominadora do mundo, tornou-se a terra prometida, o lugar dos sonhos, o 
SANTOS, André Leonardo Copetti; LUCAS, Doglas Cesar. Por uma epistemologia dos vencidos: reposicionamentos teóricos para uma responsabilidade comum universal sobre as mobilidades humanas de massa. Revista Eletrônica Direito e Política, Programa de Pós-Graduação Stricto Sensu em Ciência Jurídica da UNIVALI, Itajaí, v.13, n.3, 30 quadrimestre de 2018. Disponível em: www.univali.br/direitoepolitica - ISSN 1980-7791

território para se viver bem; mas o custo disso foi justamente tornar esta parte da Europa acessível somente de modo seletivo. O reforço de seu interior tornou ainda mais frágil e evidente a dilaceração de seu entorno. Ao não contribuir para a reconstrução dos países que Ihe fazem fronteira ou que estão mais distantes, a Europa reforçou os limites do seu interior com aquilo que the é estranho. Habermas ${ }^{8}$ alertou sobre o fato de que a Europa seria demandada cada vez mais por imigrantes e refugiados se não tomasse medidas para melhorar as condições de vida das Europas central e oriental.

Não estamos falando de turistas, de imigrantes voluntários, mas de pessoas que encontram no refúgio a única possibilidade para continuarem vivas, como alternativa para sobrevivência. A precariedade anunciada por Butler ${ }^{9}$ encontra nos recentes fluxos migratórios e de refugiados sua faceta mais crua. É o bios, numa forma nua, manifestando-se, requerendo proteção e satisfação das necessidades mais simples para a permanência da vida. A imigração em condições vulneráveis afigura-se como cuidado de si, do corpo, de sua biografia, e é, antes de tudo, um ato de desespero que não pode ser olvidado como se determinadas vidas fossem desmerecedoras de luto. Os imigrantes têm suas vidas substancialmente precarizadas e tornadas passíveis de suportarem a carga da exclusão e da dor sem lamentos de ninguém. Vidas que não são consideradas, passíveis de serem destruídas, e que não merecem reconhecimento. Vidas precárias, desperdiçadas, nuas, sem papéis, constituem-se como refugos, como sobras da globalização ${ }^{10}$. O rosto do outro parece invisível, não é notado, é descartado com certa aceitabilidade.

A vida precarizada adquire sentido na possibilidade de partir, de encontrar outro lugar. Renovar as esperanças em um novo lugar é renovar as próprias possibilidades de viver intensamente os desejos adormecidos, impedidos de se mostrarem antes desse novo acesso. Tornar a vida dos imigrantes possível, minimizar a sua precariedade, é o que deveria pautar as políticas contemporâneas de mobilidade humana. O rosto do imigrante precisa ser notado, precisa se fazer presente, precisa chocar e responsabilizar. É a sua precariedade, sua nudez e suas limitações mais naturais e mundanas que farão com que sua inscrição se instale como alteridade e reconhecimento. Ali, naquele rosto, reside um

\footnotetext{
${ }^{8}$ HABERMAS, Jürgen. Inclusão: integrar ou incorporar? Sobre a relação entre nação, Estado de direito e democracia. Revista Novos Estudos Cebrap. n. 52. São Paulo, 1998.

9 BUTLER, Judith. Vida precaria: el poder del duelo y la violência. Buenos Aires :Paidós, 2006. Da mesma autora ver, nesse sentido: Quadros da Guerra. Quando a vida é passível de luto? Rio de Janeiro: Civilização Brasileira, 2015.
}

${ }^{10}$ BAUMAN, Zygmunt. Vidas desperdiçadas. Rio de Janeiro: Jorge Zahar, 2005. 
SANTOS, André Leonardo Copetti; LUCAS, Doglas Cesar. Por uma epistemologia dos vencidos: reposicionamentos teóricos para uma responsabilidade comum universal sobre as mobilidades humanas de massa. Revista Eletrônica Direito e Política, Programa de Pós-Graduação Stricto Sensu em Ciência Jurídica da UNIVALI, Itajaí, v.13, n.3, 30 quadrimestre de 2018. Disponível em: www.univali.br/direitoepolitica - ISSN 1980-7791

humano que responsabiliza o outro. Levinas ${ }^{11}$ tem razão ao destacar que o rosto do outro me ordena, me demanda, me torna cúmplice, me chama à responsabilidade, e faz de sua morte invisível um problema meu.

Em setembro de 2015 a foto do menino Sírio Alan Kurdi, de 3 anos, encontrado morto numa praia Turca, foi simbolicamente a representação mais dura, pela estética da foto, de uma rotina de mortes quase banalizada de imigrantes que tentam chegar à Europa. A foto comoveu o mundo. A arte resgatou a tragédia de um acontecimento que vem ocorrendo há anos. A verdade por trás dessa foto são milhares de pessoas que têm morrido tentando entrar na Europa no ano de 2015. Pessoas que fogem da guerra, da perseguição religiosa, da falta de liberdade, da fome, e que arriscam a própria vida para garanti-la. O risco de morte parece não significar nada para quem se interessa em apenas manter-se vivo; a proximidade da morte é encarada como uma possibilidade maior do que a continuidade de uma vida sem valor. Por isso milhares de pessoas arriscam a sua vida e a de suas crianças na travessia marítima em condições nada ideais, trancadas em botes e barcos precários, na esperança de que a vida continue a ter sentido. Qualquer outro lugar promete mais do que permanecer onde se está. Não há sentido em ficar, há risco em mover-se e há incertezas quando se chega, caso isso de fato aconteça.

A imigração é, nesse caso, a alternativa única. Mas o que se tem dito dessa alternativa é que ela também não é viável, sobretudo se o destino for a Europa. Suas fronteiras estão fechadas e abrem-se apenas de modo seletivo, depois de muita burocracia e espera. 0 problema é que a vida desses imigrantes não pode esperar, não pode ser suspensa. Por isso mesmo a Europa ocidental aposta na não solução. Lava as mãos, fecha os olhos, não é responsável e, portanto, preocupa-se apenas em não aumentar o número de imigrantes em seu território. Obviamente que a Europa paga o preço de ser a melhor opção. E o faz reforçando a proteção de seu território e de seus acessos. Ela vale ainda mais pelo fato de que é exclusiva, impenetrável, impensável para a grande maioria dos que precisam de refúgio.

Esse quadro tenderá a ser ainda mais intenso nas próximas décadas. A mobilidade humana foi facilitada pelos novos meios de transporte e o acesso à informação de como a vida se desenvolve em outro lugar permitiu decidir de maneira rápida pela partida. Seja para fazer negócios, turismo ou imigração, os lugares do mundo estão mais pertos, são previamente conhecidos, facilitam as comunicações e os deslocamentos. A vida como

\footnotetext{
${ }^{11}$ LEVINAS, Emmanuel. Alterity and transcendence. New York, Columbia University Press, 1999.
} 
SANTOS, André Leonardo Copetti; LUCAS, Doglas Cesar. Por uma epistemologia dos vencidos: reposicionamentos teóricos para uma responsabilidade comum universal sobre as mobilidades humanas de massa. Revista Eletrônica Direito e Política, Programa de Pós-Graduação Stricto Sensu em Ciência Jurídica da UNIVALI, Itajaí, v.13, n.3, 30 quadrimestre de 2018. Disponível em: www.univali.br/direitoepolitica - ISSN 1980-7791

movimento inaugurou um novo tempo para o mundo contemporâneo. A viagem para a terra prometida, da saga bíblica, teria perdurado por gerações. Os deslocamentos migratórios do século 19 não se faziam em menos de meses. Os lugares para onde se ia eram desconhecidos completamente. Nada além de parcos comentários e nenhuma imagem. Atualmente a velocidade é um atributo epocal, em todos os seus aspectos. Aceleram-se, também, as expectativas, pois a temporalização do mundo tem o condão de instituir, de criar, de inventar e produzir as próprias demandas. O efêmero, nesse sentido, como resultado do célere, alcança pessoas e instituições.

Parece evidente, até mesmo para um observador pouco atento, de que as alternativas modernas de enfrentamento dos processos migratórios contemporâneos chegaram a um alto grau de saturação e de esgotamento. Ao normatizar a mobilidade humana a partir da racionalidade nacionalista, o acesso ao mundo como mundo foi definitivamente castrado e arbitrado. Não que a ideia de comunidade que reveste o conceito de nação, como invenção, seja nova. A ambivalência é a marca dos processos comunitários e da produção de pertença e do conceito de identidade. Em sociedades mais estabilizadas e de trocas mais tímidas esta alternativa tendia a ser consideravelmente eficiente em razão de ser pouco confrontada. Na sociedade global, no entanto, esse processo de trocas mais dinâmicas tende a dar visibilidade aos acontecimentos locais, potencializar demandas específicas e tornar global problemas que durante séculos eram problemas de uma região, cultura ou país. A imigração é também uma alternativa mais plausível por que mais possível e facilitada hoje do que outrora. O mundo como lugar de novos acessos, de todos os tipos, foi potencializado e justamente por isso, mais protegido, mais regulado, mais controlado. A vida dos imigrantes pede passagem, um lugar. Os nacionais, em regra, para garantirem seus espaços exclusivos e privilegiados defendem a impossibilidade do acesso. É de acesso a mundo que estamos falando. Os direitos humanos e as políticas públicas têm a obrigação de tornarem o mundo um lugar de acessos que permita que a vida, indistintamente, se torne uma vida vivível, condição que tem sido negada a muitos humanos imigrantes, peregrinos e refugiados. 
SANTOS, André Leonardo Copetti; LUCAS, Doglas Cesar. Por uma epistemologia dos vencidos: reposicionamentos teóricos para uma responsabilidade comum universal sobre as mobilidades humanas de massa. Revista Eletrônica Direito e Política, Programa de Pós-Graduação Stricto Sensu em Ciência Jurídica da UNIVALI, Itajaí, v.13, n.3, 30 quadrimestre de 2018. Disponível em: www.univali.br/direitoepolitica - ISSN 1980-7791

\section{O ESTADO-NAÇÃO, O ESTADo DE DiREITO E O CAPITALISMO COMO ELEMENTOS CENTRAIS DAS RAZÕES TEÓRICA E PRÁTICA SOBRE AS MIGRAÇõES}

O nível de problematização teórica que se elaborou nos últimos tempos em relação aos fluxos migratórios não possui qualquer paralelo ao longo da história do pensamento humano. Se há algo de distinto em relação às migrações, mais do que o acontecimento empírico desses fenômenos, é o fato da produção teórica sobre eles e, por consequência, as possibilidades de projeção das construções acadêmicas sobre os distintos âmbitos de tomada de decisões coletivas.

Partimos do pressuposto de que a maior partedos saberes mais problematizaram e complexificaram o fenômeno das migrações do que propriamente criaram condições de possibilidade de suavizá-los civilizatoriamente. Isto tem implicado que saberes e ações políticas têm mais criado problemas aos migrantes, especialmente pelas violações de direitos humanos do que facilitado suas vidas criando condições para que os nômades contemporâneos possam, em suas diásporas, gozar de uma boa qualidade de vida.

A questão central que nos interessa colocar para discussão refere-se fundamentalmente às condições de estabelecimento de uma problematização teórica racionalmente elaborada sobre o fenômeno da mobilidade humana pelo planeta. Interessa-nos pesquisar a economia de elaboração dos saberes sobre os fluxos migratórios. A empiria do fenômeno interessa-nos como substrato de constituição de saberes e como plano de imanência para a construção de novos saberes que tenham um direcionamento ecológico em relação à existência dos migrantes em seus novos espaços vitais.

A análise da economia dos saberes sobre os fluxos migratórios nos indica a importância da convergência dos acontecimentos do Estado nação, do Estado de Direito e do capitalismo como condição essencial para a elaboração de toda uma teorização totalmente em vigência e com fortes projeções em diferentes planos de razões práticas dirigidas ao fenômeno das migrações. É no encontro desses acontecimentos, na concorrência desses processos de desterritorialização/reterritorialização que começam a se delinear as condições do estabelecimento das problematizações que ainda hoje agem sobre as ações sociais em relação aos migrantes. É no encontro desses movimentos que começam a surgir, com intensidade nunca antes vista, as condições para as elaborações teóricas acerca de como devem ser governados os migrantes, por quem, até que ponto, com qual objetivo, com que método etc. Ou seja, em outras palavras, é a partir da confluência desses movimentos que se estabelece um substrato empírico para o 
SANTOS, André Leonardo Copetti; LUCAS, Doglas Cesar. Por uma epistemologia dos vencidos: reposicionamentos teóricos para uma responsabilidade comum universal sobre as mobilidades humanas de massa. Revista Eletrônica Direito e Política, Programa de Pós-Graduação Stricto Sensu em Ciência Jurídica da UNIVALI, Itajaí, v.13, n.3, 30 quadrimestre de 2018. Disponível em: www.univali.br/direitoepolitica - ISSN 1980-7791

estabelecimento de uma problemática e de um conjunto de saberes sobre a governabilidade das mobilidades de massa.

Em primeiro lugar, o acontecimento do Estado nação constitui-se numa condição fundamental da problematização teórica sobre as migrações. Vemos, sobre isto, cinco razões importantes a serem destacadas:

- primeiro, o modelo estatal nacional significa a superação do modelo geopolítico feudal, no qual a proteção das fronteiras praticamente inexistia, havendo, no máximo, no medievo, uma proteção dos limites da propriedade-território do príncipe;

- segundo, o modelo geopolítico do Estado-nação, sendo o resultado de um processo de aglutinação, de concentração de territórios e de funções, contraria drasticamente o modelo feudal, caracteristicamente fragmentado e desconcentrado, características que favoreciam mobilidades sem controle;

- terceiro, o modelo de Estado-nação coloca a demanda, em função da extensão dos territórios adjudicados pelos príncipes, de uma nova forma de governar, não mais familiar, irresponsável e na qual os súditos eram usados fundamentalmente para a principal finalidade do poder político medieval, a proteção do território-propriedade. Num movimento histórico diverso, o Estado-nação coloca a exigência de uma arte da governamentalidade republicana, onde a população passa a ser não mais um instrumento de proteção do território, mas, em sentido totalmente distinto, uma das finalidades centrais dos atos dos governantes e o elemento central da legitimidade do poder político. Neste sentido, a constituição de imaginários nacionalistas passa a ocupar importantes espaços não só no seio das populações dos Estados nacionais, mas também se constituem como critérios de tomada de decisão para os detentores do poder político, especialmente para o estabelecimento de uma diferenciação dos interesses internos/sedentários do Estado e das sociedades nacionais e dos interesses externos;

- quarto, o movimento do Estado-nação pode ser compreendido como um movimento de homogeneização forçada de populações muitas vezes distintas e, em consequência, relacionadas obrigatoriamente ao espaço geopolítico nacional;

- quinto, sendo o resultado de processos de aglutinação, concentração e homogeneização, o Estado-nação constitui-se numa clara antípoda a tudo o que significam os processos migratórios - dissipação, desconcentração e diversidade, e esta situação de antítese entre Estado-nação e migrações leva, naturalmente, à constituição 
SANTOS, André Leonardo Copetti; LUCAS, Doglas Cesar. Por uma epistemologia dos vencidos: reposicionamentos teóricos para uma responsabilidade comum universal sobre as mobilidades humanas de massa. Revista Eletrônica Direito e Política, Programa de Pós-Graduação Stricto Sensu em Ciência Jurídica da UNIVALI, Itajaí, v.13, n.3, 30 quadrimestre de 2018. Disponível em: www.univali.br/direitoepolitica - ISSN 1980-7791

do Estado-nação como o lugar empírico e teórico privilegiado de problematização e de elaboração de saberes problematizadores do outro, do externo, do estrangeiro, do migrante, do estranho ao nacional. O que queremos destacar é que o Estado-nação, suas práticas e seus saberes, constituíram um substrato necessário e suficiente para a elaboração de uma problemática sobre o fenômeno das mobilidades humanas, justamente por estas contrariarem a lógica e os valores fundamentais da organização política nacional;

- por fim, como sexto ponto, queremos destacar a crise atual do Estado-nação, em sua perspectiva geopolítica, pela não realização das promessas da Modernidade, como ponto importante a ser considerado na sua relação com o acontecimento de condições para a construção de saberes problematizadores das mobilidades humanas pelo planeta.

Em segundo lugar, concomitantemente ao acontecimento do Estado-nação e da sua importância para a elaboração de uma problematização e um conjunto de saberes acerca das migrações, o evento do Estado de Direito é também de fundamental importância para o estabelecimento de um discurso problematizador das migrações na medida em que com ele surge a tecnologia jurídica de proteção dos valores e interesses do Estado nacional.

O modelo do Estado constitucional de Direito, forma de organização político-jurídicoadministrativa característica da modernidade, encontra nos diferentes estratos dos seus sistemas positivos de direitos fundamentais a sua forma paroxística de constituição e proteção da cidadania nacional, colocando, via de regra, o estrangeiro migrante em situação de total excepcionalidade e a migração como um problema a ser resolvido por leis. Para isto, há a necessidade de construção de um conjunto de saberes voltados à segurança do espaço e do cidadão nacional em detrimento do indivíduo que vem de fora. O modelo de Estado de Direito, em convergência com o modelo do Estado-nação, propiciara a consolidação de uma cultura e de uma tecnologia político-jurídica de proteção do nacional e, ao mesmo tempo, como lado reverso da moeda, uma cultura e uma tecnologia de restrições ao estrangeiro, notadamente através das políticas de segurança nacional.

A primeira mirada, assim, na modernidade, dirigida ao estrangeiro, que teve como ponto de partida os modelos de Estado-nação e de Estado de Direito, é uma mirada de segurança voltada a uma proposta política de sedentarização de populações em relação a um território e a uma autoridade central, falando uma mesma língua e negociando com o Estado somente através dela. 
SANTOS, André Leonardo Copetti; LUCAS, Doglas Cesar. Por uma epistemologia dos vencidos: reposicionamentos teóricos para uma responsabilidade comum universal sobre as mobilidades humanas de massa. Revista Eletrônica Direito e Política, Programa de Pós-Graduação Stricto Sensu em Ciência Jurídica da UNIVALI, Itajaí, v.13, n.3, 30 quadrimestre de 2018. Disponível em: www.univali.br/direitoepolitica - ISSN 1980-7791

Nesse aspecto é importantíssimo considerar o papel que têm jogado os direitos fundamentais de nacionalidade e políticos. Estas duas espécies de direitos fundamentais são as bases funcionais jurídicas mais fortes da lógica do Estado-nação, pois através delas é que se estrutura a vinculação sedentária das pessoas a um território, a uma autoridade central e a um sistema de direitos.

Já em relação ao estrangeiro migrante, essas duas mesmas espécies de direitos fundamentais operam de forma totalmente distinta, pois a falta de acesso a estes direitos representa o desenvolvimento de uma condição de inferioridade sociopolítica. Há, assim, uma lógica funcional de sentido reverso nesses direitos fundamentais: para o nacional, a inclusão; para o estrangeiro migrante, a exclusão.

Uma terceira influência na constituição de saberes problematizadores dos fluxos humanos vem do sistema de produção capitalista. Ao longo da história os movimentos populacionais exerceram papeis importantíssimos nos processos de desenvolvimento econômico. Os egípcios estabeleceram migrações forçadas como reserva de mão de obra para suas obras faraônicas; os gregos e romanos transferiram populações para ocupar territorialmente suas colônias; os chineses promoveram massivas migrações rurais para regiões agrícolas a serem povoadas; os árabes fizeram acompanhar sua expansão com movimentos migratórios de escravos; os governos europeus retiveram seletivamente sua população durante a primeira época da colonização da América, para promover logo colônias de assentamento e mobilizar grandes massas de indígenas e de escravos africanos como força de trabalho; os turcos implementaram, dentro de seu império, uma permanente migração seletiva para seus centros administrativos; as jovens repúblicas americanas promoveram, unanimemente, as grandes migrações do século XIX; e, no século $\mathrm{XX}$, alguns Estados promoveram migrações temporais frente à demanda laboral insatisfeita.

Na modernidade, a grande diferença que se estabeleceu em relação às outras épocas, no que concerne aos fenômenos migratórios, foi o nível de problematização/teorização e construção de tecnologias acerca dos deslocamentos humanos e sua importância para os processos de desenvolvimento das nações. Neste último aspecto o capitalismo joga um papel fundamental enquanto conjunto de saberes constituintes de um modo de racionalização dos processos de produção da riqueza, com forte projeção determinativa sobre os processos políticos de tomada de decisão coletiva por parte de governos nacionais que internacionalizavam suas ações coloniais. 
SANTOS, André Leonardo Copetti; LUCAS, Doglas Cesar. Por uma epistemologia dos vencidos: reposicionamentos teóricos para uma responsabilidade comum universal sobre as mobilidades humanas de massa. Revista Eletrônica Direito e Política, Programa de Pós-Graduação Stricto Sensu em Ciência Jurídica da UNIVALI, Itajaí, v.13, n.3, 30 quadrimestre de 2018. Disponível em: www.univali.br/direitoepolitica - ISSN 1980-7791

Os saberes capitalistas liberais sobre os grandes processos de movimentação humana vão desembocar em concepções desenvolvimentistas e estimuladoras destas mobilidades de grande porte. Basta que visualizemos os processos migratórios de colonização da América para termos uma clara ideia disto.

Já aos discursos e políticas comunistas e socialistas não podemos associar problematizações quanto à mobilidade de seus nacionais, mas, em sentido contrário, saberes de problematização e políticas de retenção da população. Os países comunistas durante a Guerra Fria desenvolveram discursos e políticas desenvolvimentistas inversas às capitalistas, no sentido de restringirem a emigração, mediante forte repressão, como forma de manutenção de seus cérebros e de sua mão-de-obra em geral.

Contemporaneamente, a tradicional visão desenvolvimentista e liberal das migrações começa a revelar-se um tanto quanto paradoxal, pois ao mesmo tempo em que propaga uma total liberalização dos fluxos de capitais e bens, busca restringir os fluxos de pessoas. Se num primeiro momento a visão liberal/desenvolvimentista assentou-se sobre políticas de estímulo migratório, hoje mudou radicalmente de posição, pois associa, via de regra, desenvolvimento das economias nacionais à restrição migratória.

Essas situações próprias da atualidade demonstram que essas distintas visões, e os saberes que thes correspondem, sobre os processos de mobilidade humana não podem ser lidas separadamente. Vejamos os casos de algumas ações políticas adotadas por algumas potências do norte do planeta em relação a este assunto. Referimo-nos especificamente às políticas restritivas recentemente positivadas na Europa e nos Estados Unidos com uma intenção declarada de restrição dos fluxos migratórios, como forma de proteção das economias e dos trabalhadores nacionais contra os estrangeiros migrantes. Estas políticas, ao mesmo tempo em que resultaram na construção de legislações altamente restritivas, como forma de estabelecer zonas de ilegalidade para conter os fluxos migratórios que não atendessem às exigências nacionais, criaram uma enorme massa de imigrantes ilegais que já se encontravam nesses países. Mas ao mesmo tempo em que foram criadas essas zonas de ilegalidade e esses contingentes populacionais de imigrantes ilegais, os governos desses Estados mantiveram esses imigrantes ilegais em seus territórios com a finalidade de manter saudáveis suas economias, sem, tampouco, causarem prejuízos aos sistemas de serviços públicos. Os imigrantes mantidos de forma proposital na condição de ilegais constituem uma massa de trabalhadores com salários bem mais baixos que os nativos, especialmente para 
SANTOS, André Leonardo Copetti; LUCAS, Doglas Cesar. Por uma epistemologia dos vencidos: reposicionamentos teóricos para uma responsabilidade comum universal sobre as mobilidades humanas de massa. Revista Eletrônica Direito e Política, Programa de Pós-Graduação Stricto Sensu em Ciência Jurídica da UNIVALI, Itajaí, v.13, n.3, 30 quadrimestre de 2018. Disponível em: www.univali.br/direitoepolitica - ISSN 1980-7791

trabalhos de menor qualificação, situação que mantém a economia bastante ativa com um custo bastante baixo ${ }^{12}$.

$\mathrm{O}$ argumento da prejudicialidade dos imigrantes às economias nacionais e aos sistemas de serviços públicos é totalmente falacioso. Há, aqui, uma grande astúcia cuja consequência é a geração de um número cada vez maior de trabalhadores sem documentos, além de um aspecto mais grave, que é a abertura de uma grande área de atuação das organizações criminosas voltadas ao tráfico e à exploração de pessoas em suas mais distintas formas.

A maioria das evidências empíricas colhidas em diferentes países tradicionalmente receptores de imigrantes demonstra exatamente o contrário aos discursos protecionistas de alguns líderes políticos nacionais ${ }^{13}$. Análises dos contextos da França ${ }^{14}$, Argentina ${ }^{15}$, Estados Unidos ${ }^{16}$ e Alemanha ${ }^{17}$ demonstram que os imigrantes não estabelecem zonas de competição com os nativos nos mercados de trabalho dos países receptores. Estudos efetuados nos Estados Unidos põem em discussão a crença de que o migrante é uma carga para os serviços sociais, demonstrando exatamente o contrário: que o seu aporte, em geral, é superior ao uso que fazem dos serviços públicos ${ }^{18}$. Assim, por exemplo, explica um grupo de trabalho da Academia Nacional de Ciências dos Estados Unidos ${ }^{19}$ :

Partindo de um modelo econômico elementar com hipóteses admissíveis, demonstra-se que a imigração gera ganhos econômicos puras para os residentes nativos, por várias razões. Em um nível básico, os imigrantes aumentam a oferta de trabalho e contribuem para a produção de novos bens e serviços. Mas devido a que recebem salários inferiores ao valor total dos bens e serviços, os trabalhadores locais em seu conjunto saem beneficiados.

\footnotetext{
${ }^{12}$ Ver a respeitoSANTOS, André Leonardo Copetti. A Repressão das Diásporas em Tempos Globais e os Direitos Humanos dos Migrantes. In: BEDIN, Gilmar (Org.). Cidadania, Direitos Humanos e Equidade. Ijuí: Editora UNIJUÍ, 2012, pp. 339-374.

${ }^{13}$ STALKER, Peter. No-Nonsense Guide to International Migration. Oxford: New Internationalist Publications, 2001; STALKER, Peter. Workers without Frontiers. London: Lynne Rienner Publishers, 2000.

${ }^{14}$ DOMENACH, H.; PICOUET, M. Lasmigraciones. Argentina: Universidad Nacional de Córdoba, 1995.

${ }^{15}$ MAGUID, Alicia. Migrantes limítrofes enla Argentina: suinserción e impacto enel mercado de trabajo. In:EstudiosdelTrabajo, № 10, Buenos Aires, ASET, 1995.

${ }^{16}$ FRIEDBERG, Rachel M.; HUNT, Jennifer. Impact of Immigrants on Host Country Wages, Employment and Growth. The Journal of Economic Perspectives. Vol. 9, n. 2, Spring, 1995, pp. 23-44. Disponível em: http://www.jstor.org/discover/10.2307/2138165?uid=3737664\&uid=2134\&uid=2479440343\&uid=2\&uid=70\&u id $=3 \&$ uid $=2479440333 \&$ uid $=60 \&$ sid $=21103583431163$.

${ }^{17}$ FREY M.;MAMMEY U., ImpactofMigration in theReceiving Countries: Germany. Genebra: IOM, 1996.

18 MÁRMORA. Lelio. Las políticas de migracionesinternacionales. Buenos Aires, Paidós, 2002.

${ }^{19}$ SMITH, James P.; BARRY, Edmonston. The Immigration Debate: Studies on the Economic, Demographic and Fiscal Effects of Immigration. Washington D.C: National Academy Press, 1998, p. 87.
} 
SANTOS, André Leonardo Copetti; LUCAS, Doglas Cesar. Por uma epistemologia dos vencidos: reposicionamentos teóricos para uma responsabilidade comum universal sobre as mobilidades humanas de massa. Revista Eletrônica Direito e Política, Programa de Pós-Graduação Stricto Sensu em Ciência Jurídica da UNIVALI, Itajaí, v.13, n.3, 30 quadrimestre de 2018. Disponível em: www.univali.br/direitoepolitica - ISSN 1980-7791

Os benefícios para a economia do país provêm de diversas fontes. Quanto ao setor da produção, a imigração permite uma maior produtividade dos trabalhadores locais que se especializam na produção de bens em que são relativamente mais eficientes. A especialização no consumo também gera ganhos.

Como justificar, então, diante de dados tão reveladores, a adoção de políticas restritivas à imigração tão fortes como as que se positivaram nos últimos tempos no norte do planeta? Cremosestar diante de mais uma grande manobra de duplicação genética do capitalismo que, em simbiose funcional com os discursos performáticos do Estado-nação e do Estado de Direito, busca criar condições históricas de exploração de mão-de-obra barata, em tempos de crises econômicas que afetam as economias dos países que constituem o berço histórico deste modelo de racionalização do modo-de-produção da riqueza.

A pergunta que aqui se coloca é: como sairmos desta trampa armada por e através das estruturas do Estado-nação, do Estado de Direito e do capitalismo em relação aos fluxos migratórios, para repensarmos os processos de mobilidade humana em termos de desenvolvimento nãos só de sistemas de produção da riqueza, mas, fundamentalmente, da qualidade de vida dos indivíduos?

\section{A INSUFICIÊNCIA DA CONCEPÇÃO LEGAL-NACIONALISTA DE CIDADANIA E DO DISCURSO EUROCÊNTRICO DOS DIREITOS HUMANOS PARA O ENFRENTAMENTO DAS MOBILIDADES DE MASSA CONTEMPORÂNEAS}

Com a emergência e consolidação do Estado-nação, a conformação jurídica da cidadania nacional formatou praticamente todas as relações entre os indivíduos e o poder político, tornando-se a mais importante referência geradora de pertença e de proteção dos direitos do homem por parte do Estado. A cidadania nacional passou a representar a forma institucional de pertencer a determinada comunidade e o limite de diferenciação em relação aos não nacionais, ou mesmo em relação aos nacionais de segunda classe, como durante muito tempo foram consideradas as mulheres e os homens não proprietários, por exemplo. A perspectiva nacionalista da cidadania funciona ideologicamente como demarcadora imaginária entre aqueles que pertencem a uma nação e aqueles que não pertencem, estabelecendo uma redução das complexidades internas, dos choques culturais, das batalhas territoriais, que precisam ser governadas e agrupadas a uma mesma maneira de pertencer a um só lugar. Por isso é que, ao longo 
SANTOS, André Leonardo Copetti; LUCAS, Doglas Cesar. Por uma epistemologia dos vencidos: reposicionamentos teóricos para uma responsabilidade comum universal sobre as mobilidades humanas de massa. Revista Eletrônica Direito e Política, Programa de Pós-Graduação Stricto Sensu em Ciência Jurídica da UNIVALI, Itajaí, v.13, n.3, 30 quadrimestre de 2018. Disponível em: www.univali.br/direitoepolitica - ISSN 1980-7791

da história moderna do Estado, a proteção das fronteiras territoriais sempre figurou como expediente indispensável para se assegurar a pureza na Nação. ${ }^{20}$

A nacionalidade condiciona o acesso dos cidadãos aos instrumentos do Estado, o qual reconhece juridicamente a igualdade entre os sujeitos e suas culturas na produção de sua sociabilidade. Isso não quer dizer que sejamos todos, sujeitos e culturas, portadores das mesmas perspectivas materiais de vida dentro da Nação, senão que a cidadania nacional, ao menos em seu sentido formal, elabora um espaço de pertença que se basta pela própria ideia de nacionalidade, imposta como um estatuto de comunidade, sem preocupar-se com a manutenção dos vínculos de outra ordem. Essa constatação faz eco a uma afirmação de Zygmunt Bauman: "O nacionalismo tranca as portas, arranca as aldravas e desliga as campainhas, declarando que apenas os que estão dentro têm direito de aí estar e acomodar-se". ${ }^{21}$

A configuração nacionalista de consciência e de pertença está diretamente relacionada com a ideologia do Estado territorial, desenvolvida no início da modernidade e apresentada como a proposta mais adequada para promover a organização sociopolítica e o desenvolvimento econômico desse período. Segundo Habermas, ${ }^{22}$ o Estado-nação conseguiu constituir-se num modelo eficiente de modernização social pelo fato de acoplar satisfatoriamente burocracia e capitalismo. A burocracia centralizada, a crescente industrialização, a maior mobilidade social e o incremento de grandes mercados tornaram possível, e até mesmo necessário, que os indivíduos se comunicassem para além de suas localidades e de suas heranças culturais específicas.

A fusão entre Estado-nação e economia nacional consubstanciou-se em um elemento fundamental para as modificações históricas, que culminaram num rápido crescimento econômico. De acordo com o filósofo frankfurtiano, as interpretações sobre o Estado nacional partem de um ponto comum: "o Estado nacional reagiu ao problema da desintegração de uma população que fora arrancada de vínculos sociais estamentais da nascente sociedade moderna". ${ }^{23}$ Nesse momento, pelo reconhecimento jurídico do indivíduo, estabelecido pela noção de direitos e deveres, a inclusão "progressiva da população no status de cidadãos (...) produz ao mesmo tempo o novo plano de uma

20 BENHABIB, Seyla. Los derechos de los otros. Extranjeros, residentes y ciudadanos. Barcelona: Gedisa, 2005.

21 BAUMAN, Zygmunt. Modernidade líquida. Tradução de Plínio Dentzein. Rio de Janeiro: Jorge Zahar, 2001, p. 203.

22 HABERMAS, Jürgen. Direito e democracia. v. II. Rio de Janeiro: Tempo Brasileiro, 1997.

${ }^{23}$ HABERMAS, Jürgen. Inclusão: integrar ou incorporar?, p. 102. 
SANTOS, André Leonardo Copetti; LUCAS, Doglas Cesar. Por uma epistemologia dos vencidos: reposicionamentos teóricos para uma responsabilidade comum universal sobre as mobilidades humanas de massa. Revista Eletrônica Direito e Política, Programa de Pós-Graduação Stricto Sensu em Ciência Jurídica da UNIVALI, Itajaí, v.13, n.3, 30 quadrimestre de 2018. Disponível em: www.univali.br/direitoepolitica - ISSN 1980-7791

integração social abstrata, mediada juridicamente" ${ }^{24}$ de modo que o complexo étnico cede lugar à elaboração de uma organização comunitária intencionalmente democrática e referida a um direito comum. Destarte, a definição de um espaço homogêneo, do ponto de vista cultural, que particularizasse uma diferença em relação a outras culturas, reflete a marcha rápida dos mercados e as necessidades funcionais do sistema capitalista, respondendo também às exigências de modernização política. Em outras palavras, as condições expansionistas da modernidade aceleraram o processo de aproximação entre comunidade política e comunidade de cultura, uma aproximação que permitiu a convergência entre Estado e nação ${ }^{25}$ e a constituição das identidades nacionais.

Por outro lado, a transição para a modernidade erodiu as formas tradicionais de comunidade e de identidade, promovendo uma profunda e dolorosa homogeneização social e cultural, capaz de transformar camponeses, burgueses, artesãos, etc., em franceses, ingleses, alemães, etc. Em uma sociedade de grande escala, o nacionalismo, que reclama um Estado para representar sua autodeterminação, consiste em uma nova fonte de imaginário social, uma forma diferente de produzir pertença e identidade em uma sociedade que precisa estabelecer laços sociais entre anônimos. ${ }^{26}$

De fato, se nas sociedades anteriores os laços de pertença eram definidos em razão da posição hierárquica e do status social que alguém ocupava no grupo - o que tende para a valorização dos vínculos de proximidade e, por vezes, dos procedimentos ritualísticos -, a modernidade nacional elabora uma identidade de natureza categórica, objetiva, caracterizada pelo compartilhamento de certos atributos por um dado agrupamento. Com o avanço das tendências nacionalistas no contexto moderno, cada cultura específica passou a postular pelo direito de autodeterminação, ${ }^{27}$ pela defesa de sua autonomia cultural e de sua soberania política, proliferando-se as exigências em torno do reconhecimento de novos Estados - reclamos que ainda não cessaram integralmente -, pois na maioria dos nacionalismos reside o argumento de que a nação somente poderá se autodeterminar quando instituir seu próprio Estado soberano. ${ }^{28} \mathrm{O}$ Estado nacional passa, então, a ser o local de encontro político e também identitário, um espaço

\footnotetext{
${ }^{24}$ HABERMAS, Jürgen. Inclusão: integrar ou incorporar?, p. 102.

${ }^{25}$ MENDÉZ, Manuel Toscano. Nacionalismo y pluralismo cultural. Algunas consideraciones. In: CARRACEDO, José Rubio; et al. Ciudadanía, nacionalismo y derechos humanos. Madrid: Trotta, 2000.

${ }^{26}$ VEJO, Tomás Pérez. Nación, identidad nacional y outros mitos nacionalistas. Oviedo: Nobel, 1999.

27 KYMLICKA, Will; STRAEHLE, Christine. Cosmopolitismo, Estado-nación y nacionalismo. Un análisis crítico de la literatura reciente. México: Universidad Nacional Autônoma de México, 2001.

28 Para maiores esclarecimentos sobre a relação entre política nacionalista e Estado, recomenda-se: BREUILLY, John. Nacionalismo y Estado. Traducción de José Pomares. Barcelona: Pomares-Corredor, 1990 e TIVEY, Leonard. El Estado nación. Tradução de Marco-AurelioGalmarini. Barcelona: Península, 1987.
} 
SANTOS, André Leonardo Copetti; LUCAS, Doglas Cesar. Por uma epistemologia dos vencidos: reposicionamentos teóricos para uma responsabilidade comum universal sobre as mobilidades humanas de massa. Revista Eletrônica Direito e Política, Programa de Pós-Graduação Stricto Sensu em Ciência Jurídica da UNIVALI, Itajaí, v.13, n.3, 30 quadrimestre de 2018. Disponível em: www.univali.br/direitoepolitica - ISSN 1980-7791

institucional e territorialmente definido, capaz de agrupar, sob um mesmo signo de cidadania, os nacionais e suas demandas comuns. Assim, segundo Habermas, "o mérito do Estado nacional consistiu, portanto, em ter resolvido dois problemas: com base em um novo modo de legitimação, ele tornou possível uma nova forma de integração social mais abstrata". ${ }^{29}$

Essa simbiose entre cidadania e nacionalidade não foi tão hermética, pois a inexistência de um povo totalmente homogêneo e de traços culturais unívocos, capazes de gerar um Estado-nação da mesma forma homogêneo, tornou frequente, ao menos em sua formulação moderna, a adoção de políticas de purificação étnica. Em consequência, foi negado o direito ao reconhecimento das minorias culturais, foram reprimidos os chamados povos "inferiores" e buscou-se conquistar regiões vizinhas, entre outras iniciativas autoritárias que estiveram presentes em muitos momentos ideológicos e políticos dos Estados-nação. ${ }^{30}$ Neste sentido, é possível constar, na esteira de Ernest Gellner $^{31}$ que existe certo paradoxo na missão nacionalista: ao mesmo tempo em que defende uma cultura popular, elabora uma cultura dominante; aparece como protetor das tradições da velha sociedade e da diversidade cultural; no entanto, impulsiona uma cultura de massa e uniformizadora.

Destarte, a cidadania nacional não se coaduna com preferências, estamentos, divisões, ou qualquer outra característica da sociedade pré-moderna, uma vez que todas as coexistências mais ou menos diferenciadas de uma comunidade são unificadas em um único corpo político, formado por sujeitos livres e iguais em direitos perante o Estado. ${ }^{32}$ Por outro lado, essa igualdade interna, nacional, é também fortemente marcada por distinções e fragmentações jurídicas que produzem uma diferença capaz de distinguir cidadãos de não cidadãos, de separar territórios, culturas, nações, projetos e, sobretudo, de construir uma unidade pela negação de todo e qualquer tipo de diferença que não se amolde aos matizes de sua soberania. Ou seja, a unidade nacional como critério para direitos é, necessariamente, excludente e diferenciadora, pois sua diferença em relação a outras unidades é a condição mesma de sua permanência enquanto unidade.

29 HABERMAS, Jürgen. A inclusão do outro. Estudos de teoria política. Tradução de George Sperber e Paulo AstorSoethe. São Paulo: Edições Loyola, 2002, p. 128.

30 GEARY, Patrick J. 0 mito das nações. A invenção do nacionalismo. Tradução de Fabio Pinto. São Paulo: Conrad, 2005, p. 23. Na mesma direção posiciona-se ANDERSON, Benedict. Comunidades imaginadas. Reflexões sobre a origem e a expansão do nacionalismo. Tradução de Catarina Mira. Lisboa: Edições 70, 2005. Segundo Anderson, as nações são comunidades políticas imaginadas como limitadas e soberanas.

${ }^{31}$ GELLNER, Ernest. Naciones y nacionalismo. Madrid: Alianza, 1988.

32 MENDÉZ, Manuel Toscano. Ciudadanía, nacionalismo y derechos humanos. 
SANTOS, André Leonardo Copetti; LUCAS, Doglas Cesar. Por uma epistemologia dos vencidos: reposicionamentos teóricos para uma responsabilidade comum universal sobre as mobilidades humanas de massa. Revista Eletrônica Direito e Política, Programa de Pós-Graduação Stricto Sensu em Ciência Jurídica da UNIVALI, Itajaí, v.13, n.3, 30 quadrimestre de 2018. Disponível em: www.univali.br/direitoepolitica - ISSN 1980-7791

Se a cidadania nacional foi uma resposta moderna eficiente para o enfrentamento das identidades fragmentárias do período feudal, gerando uma necessária identidade coletiva pela igualdade de todos perante a lei (razão pela qual não é tão simples dissociar cidadania de nacionalidade), o pluralismo cultural presente no interior dos países e nas relações internacionais, a luta incessante das minorias por reconhecimento, bem como os problemas que afetam a humanidade como um todo (crime organizado, problemas ambientais, comércio mundial, guerras, terrorismo, fome, trocas comerciais internacionais, etc.), os quais não guardam uma relação específica com a ideia de território e de nação, não podem ser enfrentados em toda a sua complexidade por esse mesmo paradigma de cidadania e de Direito.

No atual cenário de dificuldades contemporâneas, que desafia a humanidade a encontrar respostas e soluções para os problemas que afetam indistintamente o homem como tal, independentemente de raça, nacionalidade, religião, língua, etc., a cidadania nacional pode representar um acirramento dos afastamentos e das diferenças excludentes e opressoras que tendem a propiciar violência e prejudicar uma conversação democrática e preocupada com uma proposta de direitos humanos que alcance,responsabilize e obrigue universalmente culturas, nações, religiões e Estados distintos. ${ }^{33}$

Já foi apontado, por Hannah Arendt, ${ }^{34}$ que a identificação dos direitos humanos com o Estado-nação impediu, no século XIX, que os direitos estendidos aos nacionais fossem também reconhecidos para os estrangeiros ou apátridas. Da mesma forma, no período entre guerras alguns grupos de indivíduos foram desnacionalizados, colocados para fora do Estado, situação que Ihes negava qualquer espécie de proteção. "Uma vez fora do país de origem, permaneciam sem lar; quando deixavam seu Estado, tornavam-se apátridas; quando perdiam os seus direitos humanos, perdiam todos os seus direitos: eram o refugo da terra". ${ }^{35}$ Ao constituir-se no único local de pertença, de inserção na comunidade, o Estado passou a representar a possibilidade de construir a própria identidade e de garantir um lugar no mundo. Esse processo transformou os vínculos com o Estado na única alternativa para se ter direitos, mas, paradoxalmente, na maneira mais simples de sonegá-los, pois bastava negar o direito de alguém pertencer a um

${ }^{3}$ CARBONELL, Miguel. Los derechos en la era de la globalización. In: CARBONELL, Miguel; VÄZQUEZ, Rodolfo (Orgs.). Estado constitucional y globalización. México: Porrúa, 2003, p. 325-347; MARTINEZ, José Maria Seco e PRIETO, Rafael Rodriguéz. Espacios y ritmos para una nueva concepción de la ciudadanía. In: JULIOSCAMPUZANO, Alfonso (Editor). Ciudadanía y derecho en la era de la globalización. Madrid: Dykinson, 2007, p. 327-341.

34 ARENDT, Hannah. Origens do totalitarismo. Tradução de Roberto Raposo. São Paulo: Companhia das Letras, 1989.

${ }^{35}$ ARENDT, Hannah. Origens do totalitarismo, p. 300. 
SANTOS, André Leonardo Copetti; LUCAS, Doglas Cesar. Por uma epistemologia dos vencidos: reposicionamentos teóricos para uma responsabilidade comum universal sobre as mobilidades humanas de massa. Revista Eletrônica Direito e Política, Programa de Pós-Graduação Stricto Sensu em Ciência Jurídica da UNIVALI, Itajaí, v.13, n.3, 30 quadrimestre de 2018. Disponível em: www.univali.br/direitoepolitica - ISSN 1980-7791

Estado para negar-lhe todos os direitos humanos, ou, no máximo, submetê-lo a um regime jurídico excepcional. Por isso a filósofa alemã entendia que o direito de pertencer a uma comunidade era a condição indispensável para se poder ter direitos, ou, em outras palavras, um direito primeiro que possibilitaria a proteção dos direitos de cidadania pela comunidade à qual se pertence.

Se a cidadania e os direitos humanos permanecerem tolhidos à perspectiva da positivação nacionalista, excluindo qualquer projeto complementar, muitos dos temas que caracterizam a luta pelos direitos humanos na contemporaneidade serão praticamente sonegados. A luta humana pela autonomia e pelo reconhecimento não pode ser aprisionada nos estreitos limites do procedimentalismo jurídico e dos dogmas positivistas cartesianos. A procura responsável pelo direito à dignidade de cada homem é uma procura que exige, simbolicamente, a conquista de muitos espaços, não apenas do direito e, sobretudo, não apenas do direito nacional. Uma cidadania que se basta na soberania nacional é uma cidadania que não alcança a racionalidade das demandas materiais globais, bem como usurpa da humanidade a possibilidade de enfrentar democraticamente os problemas que afligem o homem em sua condição de exercer de forma livre a sua autonomia por meio da liberdade de decidir. Reduzida aos termos jurídicos nacionais, a cidadania é contrária ao universalismo dos direitos humanos e um privilégio gerador de discriminação, ou, como diria Luigi Ferrajoli, "a última relíquia prémoderna das diferenciações por status...". ${ }^{36}$

Falar em uma cidadania pós-nacional, pois, significa defender que a concepção de cidadania no contexto da sociedade contemporânea pode e deve ser dissociada da ideia de nacionalidade ou de comunidade particular de cultura. ${ }^{37} \mathrm{~A}$ perspectiva pós-nacional exige a afirmação de espaços democráticos que sejam capazes de estimular o encontro entre as diversas vozes preocupadas em enfrentar os problemas que alcançam a sociedade de modo transnacional. Construir instituições transnacionais que ultrapassem a dinâmica da nacionalidade poderá representar um passo importante para a convivência pacífica entre os Estados, cada vez mais fragilizados em razão de demandas e problemas de ordem global que os afetam, independentemente de sua localização territorial

\footnotetext{
${ }^{36}$ FERRAJOLI, Luigi. Más allá de la soberanía y la ciudadanía: Un constitucionalismo global. In: CARBONELL, Miguel; VÁZQUEZ, Rodolfo (Orgs.). Estado constitucional y globalización. México: Porrúa, 2001, p. 313324.

37 ESTRADA, Isabel. De Westefália ao projecto pós-nacional. In: PUREZA, José Manuel (Org.). Para uma cultura da paz. Coimbra: Quarteto, 2001; CARVALHAIS, Isabel Estrada. Os desafios da cidadania pósnacional. Porto: Edições Afrontamento, 2004.
} 
SANTOS, André Leonardo Copetti; LUCAS, Doglas Cesar. Por uma epistemologia dos vencidos: reposicionamentos teóricos para uma responsabilidade comum universal sobre as mobilidades humanas de massa. Revista Eletrônica Direito e Política, Programa de Pós-Graduação Stricto Sensu em Ciência Jurídica da UNIVALI, Itajaí, v.13, n.3, 30 quadrimestre de 2018. Disponível em: www.univali.br/direitoepolitica - ISSN 1980-7791

específica. ${ }^{38}$ Uma cidadania desse tipo é uma cidadania qualificada em termos de intervenção, pois, ao mesmo tempo em que não nega os vínculos jurídicos com o território, expande-se para além dele e para além de seu fundamento.

É preciso destacar, então, que a concepção de cidadania nacional, restrita a uma normatização interna com objetivos também internos ao Estado nacional, por mais que cumpra um papel fundamental para a constituição do Self, precisa ser refletida e complementada por uma perspectiva universalizável de preocupações, responsabilidades e respostas não autoritárias em âmbito global. A cidadania pós-nacional ou qualquer outro nome que se preferir, é o ainda-não ou o não-ainda como diria Falk, ${ }^{39}$ um projeto em andamento, uma ideia a ser elaborada e a ser construída pelas diferenças que se reúnem e que se identificam na convergência das necessidades contextuais, particulares, que caracterizam a humanidade do homem em seu diverso acontecer. Trata-se, portanto, de uma cidadania em nome da humanidade, uma cidadania preocupada em promover um diálogo que aproxime lugares, pessoas, costumes, Estados, religiões, etc., estabelecendo reciprocidades e a proteção das diferenças que não afrontem a igual dignidade que reside em cada ser humano em sua universalidade. ${ }^{40}$

\section{SOBRE A RESPONSABILIDADE COMUM UNIVERSAL PELOS DIREITOS HUMANOS DOS MIGRANTES}

Uma cultura de responsabilidades comuns, uma ética para além das nações e das soberanias, representa uma reação às singularidades do mundo moderno que parece erodir-se aos poucos diante das novas tendências globais. Uma reação centrada em bens, valores e interesses humanos universais capazes de obrigar o homem a respeitar a vida e a responsabilizar-se pela sua preservação, e pela proteção do planeta e do homem, independentemente de sua nacionalidade, etnia, religião, etc. No instante em que o mundo se constitui como um mosaico de problemas, que os Estados não protagonizam quase nada isoladamente, que aumentam os níveis de interdependência global em praticamente todos os campos de sociabilidade, que os objetivos da humanidade caminham para uma convergência cada vez mais indivisível, comunidades separadas e isoladas, soberanas a todo custo, diminuem as possibilidades de diálogo, restringem o poder da ação política em escala global e impedem que a responsabilidade

\footnotetext{
38 VIEIRA, Liszt. Cidadania e globalização. Rio de Janeiro: Record, 1997.

39 FALK, Richard. Uma matriz emergente de cidadania: complexa, desigual e fluida. In: BALDI, César Augusto (Org.). Direitos humanos na sociedade cosmopolita. Rio de Janeiro: Renovar, 2004.

${ }^{40}$ ARAUJO, José Antonio Estévez. Ciudadanía cosmopolita versus globalización neoliberal. In: GORSKI, Héctor C. Silveira (Org.). Identidades comunitárias y democracia. Madrid: Trotta, 2000.
} 
SANTOS, André Leonardo Copetti; LUCAS, Doglas Cesar. Por uma epistemologia dos vencidos: reposicionamentos teóricos para uma responsabilidade comum universal sobre as mobilidades humanas de massa. Revista Eletrônica Direito e Política, Programa de Pós-Graduação Stricto Sensu em Ciência Jurídica da UNIVALI, Itajaí, v.13, n.3, 30 quadrimestre de 2018. Disponível em: www.univali.br/direitoepolitica - ISSN 1980-7791

se dê em razão de temas que interessam à humanidade do homem como tal. Para Bertran Badie, os problemas e objetivos da humanidade são cada vez mais os problemas de cada indivíduo, de cada nação, de modo que, todos afetados, indivíduos, culturas, países, religiões, etc., os objetivos comuns da humanidade, "racional e eticamente, (...) exigem um tratamento global no qual o princípio de responsabilidade se substitui ao de soberania: cada Estado é responsável pela sobrevivência do planeta, pelo seu desenvolvimento e pelos valores construídos como universais". ${ }^{41}$

Os direitos humanos, nessa direção, configuram-se como tradução de um sistema ético ${ }^{42}$ e jurídico transnacional de corresponsabilidades para além das soberanias, preocupado com o reconhecimento dos problemas humanos enquanto tais, assim como com o estabelecimento de uma cultura política, jurídica e institucional de comprometimento com o humano. ${ }^{43}$ Sem uma ética transnacional, a globalização dos mercados e o avanço tecnológico não se colocarão a serviço do desenvolvimento dos povos e das nações, mas alimentarão as diferenças que separam os países ricos dos pobres, e a diversidade entre as culturas será incapaz de promover diálogos cosmopolitas, que se estabeleçam para além do encerramento solipsista de cada cultura ou dos interesses nacionais protegidos pela soberania. ${ }^{44}$

Reconhecer-se no outro é condição para responsabilizar-se com ele e com o mundo. Aceitar tratar dos problemas da humanidade como sendo seus próprios problemas, e ter a consciência de que inexistem regiões, religiões, culturas, economias totalmente imunes aos efeitos da civilização contemporânea, significa a possibilidade de reinventar lugares de responsabilidade e de liberdade, e, além disso, ampliá-los para fora da clausura nem sempre elogiável das soberanias e das fronteiras nacionais.

Os riscos e os medos do presente, projetados de modo ameaçador para o devir, exigem, especialmente na civilização tecnológica, dirá Hans Jonas, ${ }^{45}$ uma ética para o futuro

${ }^{41}$ BADIE, Bertrand. Um mundo sem soberania. Os Estados entre o artifício e a responsabilidade. Lisboa: Piaget, 2000, p. 17. 91.

${ }^{42}$ GARCÍA, Eusébio Fernández. Dignidad humana y ciudadanía cosmopolita. Madrid: Dykinson, 2001, p.

43 Ver, nesse sentido, JULIOS-CAMPUZANO, Alfonso. Globalización ilustrada. Ciudadanía, derechos humanos y constitucionalismo. Madrid: Dykinson, 2003; PUREZA, José Manuel. El patrimonio común de la humanidad. ¿Hacia un derecho internacional de la solidariedad? Madrid: Trotta, 2002.

${ }^{44}$ CORTINA, Adela. Una ética transnacional de corresponsabilidad. In: SERRANO, Vicente (Editor). Ética y globalización. Cosmopolitismo, responsabilidad y diferencia en un mundo global. Madrid: Biblioteca Nueva, 2004. Nesse sentido, ver CARDUCCI, Michele. Por um direito constitucional altruísta. Porto Alegre: Livraria do Advogado, 2003.

45 JONAS, Hans. O princípio responsabilidade. Ensaio de uma ética para a civilização tecnológica. Rio de Janeiro: Contraponto; Puc-Rio, 2006. Ver, ainda, CRUZ, Manuel. Responsabilidad en tiempos de 
SANTOS, André Leonardo Copetti; LUCAS, Doglas Cesar. Por uma epistemologia dos vencidos: reposicionamentos teóricos para uma responsabilidade comum universal sobre as mobilidades humanas de massa. Revista Eletrônica Direito e Política, Programa de Pós-Graduação Stricto Sensu em Ciência Jurídica da UNIVALI, Itajaí, v.13, n.3, 30 quadrimestre de 2018. Disponível em: www.univali.br/direitoepolitica - ISSN 1980-7791

baseada na responsabilidade, capaz de orientar para a preservação da espécie humana e do mundo em sua presença, de pautar deveres que impliquem num tempo vindouro, enfim, de responsabilizar-se com o futuro mesmo que isso signifique, desde já, estabelecer renúncias, responsabilidades para todos e a negação dos egoísmos nacionais e individuais que separam fortes e fracos, possuidores daqueles que continuam aspirando a possuir. Os desafios que afetam a humanidade devem aconselhar e ensinar o homem a agir, a assumir as obrigações em prol de seu próprio futuro. Mas essa missão de responsabilidade restará prejudicada se a racionalidade técnica, que toma conta do mundo em tons cada vez mais fortes, somar-se às racionalidades política e jurídica, que guarnecem os interesses nem sempre responsáveis dos Estados soberanos. Da mesma forma que a ética tradicional não consegue orientar o mundo inaugurado pela técnica, também as soberanias nacionais serão incapazes de produzir uma realidade de reciprocidades baseada na universalidade dos direitos humanos, uma vez que nem sempre as convergências necessárias ao respeito a tais direitos são alcançadas pelo jogo político e econômico das relações internacionais tradicionais.

Em vez de se propor o enfrentamento dessa espécie de um novo pluralismo ${ }^{46}$ pela defesa de um perigoso fechamento em torno de si mesmo, das nações, etnias, religiões, países, no sentido de reforçar os laços identitários e as políticas locais isolacionistas, parece mais sensato, de acordo com André-Jean Arnaud, que o futuro seja construído com a ampliação das formas democráticas, seja pela institucionalização de espaços supranacionais de decisão política, seja pela valorização de mecanismos de governança mundial ${ }^{47}$ que, de modo interativo, dinâmico e projetivo, possibilitem a gestão dos negócios públicos locais, regionais e mundiais, pela participação e decisão das instituições públicas, do setor privado e da sociedade civil conjuntamente.

Isso significa que as soberanias precisam ajustar sua participação no jogo de forças mundial, atendendo a critérios formais de exercício do poder, a ser manifesto de forma cada vez mais compartilhado e, sobretudo, observando o rigor de uma normativa mundial de direitos humanos que substancializa, interna e externamente, a validade dos

globalización. In: SERRANO, Vicente (Editor). Ética y globalización. Cosmopolitismo, responsabilidad y diferencia en un mundo global. Madrid: Biblioteca Nueva, 2004.

46 ARNAUD, André-Jean. O direito entre modernidade e globalização. Lições de filosofia do direito e do Estado. Tradução de Patrice Charles Wuillaume. Rio de Janeiro: Renovar, 1999.

47 ARNAUD, André-Jean. Governar sem fronteiras. Entre globalização e pós-globalização. Rio de Janeiro: Lúmen Júris, 2007. Ver ainda, do mesmo autor, La gouvernanceglobale, une alternativeaudroitinternational? In: Revista de Direito Internacional e Econômico. n. 9, out./nov./dez. de 2004 e ROSENAU, James. A cidadania em uma ordem mundial de mutação. In: ROSENAU, James; CZEMPIELL, Ernest-Otto (Orgs.). Governança mundial sem governo. Ordem e transformação na política mundial. Tradução de Sérgio Bath. Brasília: UnB, 2000. 
SANTOS, André Leonardo Copetti; LUCAS, Doglas Cesar. Por uma epistemologia dos vencidos: reposicionamentos teóricos para uma responsabilidade comum universal sobre as mobilidades humanas de massa. Revista Eletrônica Direito e Política, Programa de Pós-Graduação Stricto Sensu em Ciência Jurídica da UNIVALI, Itajaí, v.13, n.3, 30 quadrimestre de 2018. Disponível em: www.univali.br/direitoepolitica - ISSN 1980-7791

atos de soberania. Por isso, manter a soberania identificada com a promoção do autointeresse, sem ampliar as suas perspectivas fundantes, significa, além de reproduzir as já conhecidas formas de distinções excludentes, fragilizar a potencialidade emancipatória dos direitos humanos e impedir que se forme uma cultura ética para além dos espaços de produção da vida estatal e jurídica tradicionais. É necessário então, como lembra Ulrich Beck, "refletir sobre formas que possibilitem redistribuir os direitos de soberania, até agora fixados no delimitado espaço do nacional, em três direções que transponham o âmbito dos Estados individuais territorialmente definidos: para dentro, na sociedade; para baixo, no plano local; e para fora, nas novas redes de decisão e nos pontos nodais das arenas políticas transnacionais". 48

A imigração como um problema que implica o mundo e não um Estado em particular, jamais será equacionada enquanto forem mantidas as narrativas que constroem a identidade, seja ela qual for, de modo ambivalente e excludente, como no caso nacionalista. A modernidade construiu um formato e um estatuto jurídico para a pertença que se alimenta do seu oposto. O estrangeiro, o imigrante, o refugiado, foram reforçados de modo negativo pelo nascimento do cidadão nacional. Com vínculos mais claros e objetivos, o indivíduo moderno foi colonizado pela ideia de nacionalidade e sua diferença mais fácil de ser identificada. Ou assimila, converte-se, aceita seu novo vínculo, o é perseguido, colocado para fora, barrado seu acesso.

Sem desconstruir esse discurso que ecoa nas instituições de modo potente, o empenho em deixar imigrantes indesejados para fora será bem mais eficiente do que integrá-los. A descartabilidade do imigrante está se instalando como regra e, fora iniciativas pontuais, nada parece indicar um cenário próximo de otimismo. No debate político, nas estratégias econômicas, nas ações militares, nas práticas de segurança, nas lógicas comunicacionais, o imigrante tem sido descrito como uma espécie de novo bárbaro. Seu estranhamento amedronta; sua diferença provoca reações. Esses desencontros ainda cobrarão um preço, pois a vida continua, prossegue, mesmo de modo que não nos agrade. Tais situações de estranhamento têm resultado, na maior parte dos casos, em legislações nacionais cujo sentido é a proteção do espaço e da ordem internos e, em sentido inverso, a repressão e negação de direitos aos migrantes.

Definitivamente é necessário ver mais humanidade no imigrante que imigrante no homem. Nossas diferenças não podem nos impedir de acessar o mundo, pois são

\footnotetext{
${ }^{48}$ BECK, Ulrich. Liberdade ou capitalismo. Tradução de Luiz Antônio Oliveira de Araújo. São Paulo: Unesp, 2003 , p. 206
} 
SANTOS, André Leonardo Copetti; LUCAS, Doglas Cesar. Por uma epistemologia dos vencidos: reposicionamentos teóricos para uma responsabilidade comum universal sobre as mobilidades humanas de massa. Revista Eletrônica Direito e Política, Programa de Pós-Graduação Stricto Sensu em Ciência Jurídica da UNIVALI, Itajaí, v.13, n.3, 30 quadrimestre de 2018. Disponível em: www.univali.br/direitoepolitica - ISSN 1980-7791

condições de nosso acesso mais rico. É na troca, nos encontros, no diálogo, que o mundo contruiu-se como mundo. E é nessa mesma dinâmica que o sujeito se constitui como sujeito. Por isso tudo, negar o outro é a forma mais óbvia de negar-se a si mesmo.

5 ESBOÇANDO UMA EPISTEMOLOGIA DOS VENCIDOS. ELEMENTOS PARCIAIS, INICIAIS E INDICATIVOS PARA UMA NOVA VISÃO DA RESPONSABILIDADE COMUM UNIVERSAL SOBRE OS DIREITOS HUMANOS DOS MIGRANTES

As políticas de controle dos fluxos de corpos foram e continuam sendo políticas majoritariamente pensadas dentro do marco do Estado-nação, ou, na melhor das hipóteses, dentro de espaços confederativos, como a União Europeia, com a tecnologia jurídica de controle do Estado de Direito, e com sentido fortemente dado pelos interesses do capitalismo.

Entretanto, a realidade epocalmente particular dos fluxos próprios da globalização, revela que estes são fenômenos que se manifestam, no plano empírico, muito além das fronteiras nacionais, e no plano teórico, reclamam a ultrapassagens de qualquer tentativa de disciplinarização dogmática e de controle mediante sistemas jurídicos repressivos.

Por outro lado, é preciso que tomemos em consideração que alguns países extremamente importantes na configuração político-econômica mundial da atualidade, como, por exemplo, China e a maior parte dos países europeus, passam por fenômenos de decréscimo de natalidade, o que poderá, num futuro próximo, ter significativos reflexos sobre a disponibilidade de mão-de-obra. Segundo o Relatório do IMI a tendência fundamental para a definição das migrações é a taxa de natalidade de alguns países:

O declínio mundial das taxas de natalidade poderá vir a colocar em questão a hipótese de existência de um viveiro inesgotável de migrantes laborais, prontos a deslocar-se para os países industrializados, com vista a prover às necessidades econômicas. À medida que os países forem avançando na transição demográfica, as suas taxas de dependência aumentarão nos próximos decênios. A médio e longo prazos, uma concorrência acrescida no acesso a mão-de-obra poderá transformar radicalmente as migrações mundiais e as respostas políticas de maneira dificilmente imaginável ${ }^{49}$.

A China, novo gigante industrial, é com sua fraca taxa de natalidade candidata a déficit de mão-de-obra importante, caso continue mantendo suas taxas de crescimento e restrição à natalidade. Esse mesmo relatório alerta ainda que, em longo prazo, regiões

\footnotetext{
${ }^{49}$ INTERNATIONAL MIGRATION INSTITUTE (IMI). Towards a New Agenda for International Migration Research. Universityof Oxford, 2006, p. 13.
} 
SANTOS, André Leonardo Copetti; LUCAS, Doglas Cesar. Por uma epistemologia dos vencidos: reposicionamentos teóricos para uma responsabilidade comum universal sobre as mobilidades humanas de massa. Revista Eletrônica Direito e Política, Programa de Pós-Graduação Stricto Sensu em Ciência Jurídica da UNIVALI, Itajaí, v.13, n.3, 30 quadrimestre de 2018. Disponível em: www.univali.br/direitoepolitica - ISSN 1980-7791

da América Latina e Norte da África podem sofrer consequências do rápido decréscimo das taxas de natalidade registradas nas últimas décadas.

A mobilidade contemporânea traz, além do dinamismo das migrações internacionais, a ilegalidade, o tráfico de pessoas, a xenofobia e a usurpação dos diretos do migrante. Para o enfrentamento destes problemas as ações não podem ser unilaterais, é necessário esforço conjunto de diálogo e cooperação, respeitando a soberania nacional, mas reconhecendo a complexidade das questões, para organizar foros e ações políticas internacionais.

Para tanto, precisamos refazer nossos saberes sobre um fenômeno que nas últimas décadas mudou completamente sua face. Assim, pensamos em algumas linhas investigativas, como novas possibilidades hermenêuticas para a elaboração de ações políticas e jurídicas libertadores, fora dos marcos do Estado-nação, pelas quais devemos nos enveredar diante desses câmbios que sofreram os processos migratórios em razão da globalização:

- $\quad$ Em primeiro lugar, qualquer investigação que queira ter um mínimo de imanência ao mundo contemporâneo deve considerar que, conforme alerta Badie ${ }^{50}$, o enorme crescimento dos fluxos transnacionais, a proliferação das redes e o fracasso da relação cidadã que se verifica um pouco por todo o lado, enfraquecem inevitavelmente - em particular fora da Europa - o território do Estado-nação que, cada vez menos, pode ter pretensões a beneficiar a fidelidade prioritária dos indivíduos. É preciso ter em conta que se formam tendências em que a multiplicidade parece triunfar sobre o uno, em que os nomadismos parecem ser tão cotidianos quanto os sedentarismos;

- $\quad$ Segundo, é preciso interpretar as migrações como parte integrante dos processos de transformação mundial mais do que como um problema a resolver. As investigações devem se concentrar sobre as relações recíprocas entre os processos migratórios e as transformações econômicas e sociais. É necessário estudar os dois lados da migração: na sua origem - as causas de sua gênese - e de outro, o acolhimento - nos problemas e nas políticas de integração;

- Também é inevitável articular os padrões migratórios atuais com as tendências históricas, analisando as continuidades e as descontinuidades. As migrações devem ser reconhecidas como um processo, com continuidades temporais de décadas ou séculos, reconhecer este fato ajuda a entender as zonas de descontinuidade e suas características

\footnotetext{
${ }^{50}$ BADIE, Bertrand. O Fim dos Territórios. Ensaios sobre a desordem internacional e sobre a utilidade social do respeito. Lisboa: Instituto Piaget, 1995.
} 
SANTOS, André Leonardo Copetti; LUCAS, Doglas Cesar. Por uma epistemologia dos vencidos: reposicionamentos teóricos para uma responsabilidade comum universal sobre as mobilidades humanas de massa. Revista Eletrônica Direito e Política, Programa de Pós-Graduação Stricto Sensu em Ciência Jurídica da UNIVALI, Itajaí, v.13, n.3, 30 quadrimestre de 2018. Disponível em: www.univali.br/direitoepolitica - ISSN 1980-7791

estruturais. É premente combater o mito de que as migrações são "anomalias" da modernidade;

- Num plano socioantropológico, não há como não aproximar a compreensão das migrações ao nível micro das tendências ao nível macro. As análises devem contemplar as motivações à emigração desde a esfera individual, familiar, comunitária até as políticas macroeconômicas;

- Numa perspectiva mais projetiva, torna-se importante olhar para o futuro desenvolvendo cenários de tendências migratórias e tomando em consideração as mudanças demográficas, econômicas e políticas. As transformações socioeconômicas globais têm relações recíprocas com as dinâmicas migratórias, este é o ponto de partida para traçar as tendências do cenário das migrações;

- No campo investigativo relacionado ao Estado de Direito, é importante repensar a funcionalidade dos direitos fundamentais de nacionalidade e políticos, de forma a suavizar e facilitar o acesso a estas espécies de direitos aos migrantes que objetivem a permanência no território do país de destino;

- É necessário também considerar a complexidade das sociedades contemporâneas, cada vez mais multiculturais, a fim de que possamos elaborar saberes capazes de gerar ações políticas inclusivas, a partir de diálogos interculturais. Como, em função dos fluxos migratórios, surgem comunidades em todo mundo cada vez mais diversificadas, a forma de gestão da diversidade torna-se um dos principais desafios para o futuro. Cidades bem-sucedidas e as sociedades do futuro serão mais e mais multiculturais. Assim, gerir e explorar o potencial da diversidade cultural para estimular a criatividade e a inovação e, consequentemente, gerar prosperidade econômica e uma melhor qualidade de vida, tornam-se desafios a serem enfrentados não só no futuro, mas já nos dias atuais. A diversidade pode ser um recurso para o desenvolvimento de uma cidade se o discurso público, as instituições e os processos da cidade, bem como o comportamento das pessoas, levar em conta a diversidade de forma positiva.

- $\quad$ Ainda considerando a complexidade das sociedades contemporâneas, cremos que seja de fundamental importância inserirmos nossas investigações dentro de marcos teóricos que contemplem soluções ligadas à cooperação econômica entre norte e sul, numa perspectiva diacrônica, pois os países sulistas, e mais especificamente da América Latina, têm muito contribuído com os desafogamentos populacionais históricos que o norte do planeta precisou fazer, em função de crises econômicas, como forma de equilibrar suas economias. É chegada a hora de pensarmos fluxos humanos como alternativas de desenvolvimento tanto para países desenvolvidos como para os nãodesenvolvidos e os em desenvolvimento; 
SANTOS, André Leonardo Copetti; LUCAS, Doglas Cesar. Por uma epistemologia dos vencidos: reposicionamentos teóricos para uma responsabilidade comum universal sobre as mobilidades humanas de massa. Revista Eletrônica Direito e Política, Programa de Pós-Graduação Stricto Sensu em Ciência Jurídica da UNIVALI, Itajaí, v.13, n.3, 30 quadrimestre de 2018. Disponível em: www.univali.br/direitoepolitica - ISSN 1980-7791

- $\quad$ No campo de constituição de um pensamento latino-americano, pensamosser incontornável pensar/considerar nossos fenômenos regionalizados de mobilidade humana, a fim de podermos elaborar um campo de imanência teórica que permita territorializar soluções adequadas às nossas demandas reais, e não simplesmente repetir soluções alienígenas, especialmente do norte do planeta.

Para finalizar, devemos considerar a recomendação da CEPAL, que propõe um acordo global sobre as políticas migratórias, estabelecendo um consenso e uma responsabilidade internacionais, pois em matéria de políticas públicas sobre migração, a globalização tornará cada vez mais necessário o trânsito do controle migratório para a gestão migratória num sentido amplo, o que não significa que os Estados abandonem sua atribuição de regulamentar a entrada de estrangeiros e acautelar suas condições de radicação, mas que aceitem formular políticas razoáveis de admissão, que contemplem a permanência, o retorno, a reunificação familiar, a revinculação, o trânsito fronteiriço e o translado de indivíduos a outros países ${ }^{51}$.

\section{CONSIDERAÇÕES FINAIS}

O conhecimento que tem sido produzido acerca dos processos migratórios, e que tem se projetado nas ações políticas de enfrentamento dessa grave questão, tem obedecido, majoritariamente, os marcos do Estado-nação, do Estado de Direito e do capitalismo. As soluções políticas que têm sido engendradas a partir deles não têm dado resultados satisfatórios, especialmente no que tange a uma inclusão efetiva dos migrantes nos países e comunidades receptoras.

Os problemas decorrentes desses fenômenos têm sido enfrentados basicamente através de perspectivas políticas e jurídicas nacionais, com um sistema de responsabilidades totalmente vinculado aos governos e direitos nacionais, quando, em sua essência, o fenômeno não respeita qualquer espécie de fronteiras artificialmente criadas e reclama outras alternativas que ultrapassem o modelo nacionalista, especialmente aqueles cujo sentido é dado pela ideia de segurança nacional.

A superação desses modelos esgotados depende da produção de novos saberes, fora dos marcos antes citados, especialmente pelo fato de terem sido produzidos, em sua maior parte, desde um lugar de enunciação situado no norte do planeta. É preciso, antes de

51 CEPAL/NACIONES UNIDAS. Globalização e Desenvolvimento. 2002, p. 267. Disponível em: http://www.eclac.cl/publicaciones/xml/9/10029/GlobalizacionPortuguesCap8.pdf. Acesso em: 08 Nov. 2018. 
SANTOS, André Leonardo Copetti; LUCAS, Doglas Cesar. Por uma epistemologia dos vencidos: reposicionamentos teóricos para uma responsabilidade comum universal sobre as mobilidades humanas de massa. Revista Eletrônica Direito e Política, Programa de Pós-Graduação Stricto Sensu em Ciência Jurídica da UNIVALI, Itajaí, v.13, n.3, 30 quadrimestre de 2018. Disponível em: www.univali.br/direitoepolitica - ISSN 1980-7791

mais nada, mudar o lugar de enunciação teórica, para que possamos mudar o sentido das ações políticas e jurídicas. É preciso que incluamos nos novos saberes, numa espécie de contrarrelato crítico, uma visão de conjunto do fenômeno e seus problemas, não desprezando a visão garantista dos direitos humanos, mas modulando-a para incluir como a parte mais importante a perspectiva dos migrantes, as causas e consequências de seus deslocamentos, as suas necessidades e possibilidades de integração e inclusão.

Com efeito, os problemas teóricos que deveremos resolver, para mudar radicalmente a face das políticas públicas e soluções jurídicas voltadas aos fenômenos de mobilidade de massa, devem ficar marcados desde a perspectiva que apontara há anos o fundador da Escola de Marburgo, o neokantiano e judeu Hermann Cohen, quando expressava que o método crítico consiste em colocar-se no espaço político dos pobres, das vítimas e desde aí levar a cabo a crítica das patologias do Estado. Desde o lugar epistemológico - o das vítimas, as do sul político do planeta, que muitas vezes situa-se no norte, nos termos enunciados por Boaventura de Souza Santos, os oprimidos, os excluídos, os novos movimentos populares, os povos ancestrais colonizados pela Modernidade, pelo capitalismo que se globaliza, tudo o que fica expressado, utilizando a expressão de Dussel, em redes mundiais altermundistas, em substituição ao termo terceiro-mundista, expressão que traduz melhor a luta por um outro mundo, onde caibam todos os mundos.

O que estamos propondo é uma espécie de descolonização dos saberes acerca das migrações, livres dos "abcessos de fixação" territoriais na expressão de Marc Augé52, comprometidos com a pluralidade de culturas e etnias e voltado a desfazer as propostas nacionalistas de homogeneidade dos seus cidadãos, de modo a retornar a definir a Diferença, com seus respectivos direitos e deveres novos.

\section{REFERÊNCIA DAS FONTES CITADAS}

ANDERSON, Benedict. Comunidades imaginadas. Reflexões sobre a origem e a expansão do nacionalismo. Tradução de Catarina Mira. Lisboa: Edições 70, 2005.

ARAUJO, José Antonio Estévez. Ciudadanía cosmopolita versus globalización neoliberal. In: GORSKI, Héctor C. Silveira (Org.). Identidades comunitárias y democracia. Madrid: Trotta, 2000.

ARENDT, Hannah. Origens do totalitarismo. Tradução de Roberto Raposo. São Paulo: Companhia das Letras, 1989.

ARISTÓTELES. Política. São Paulo: Martin Claret, 2002, p. 125.

\footnotetext{
52 AUGÉ, Marc. Por uma antropologia da mobilidade. Maceió: EDUFAL: UNESP, 2010.
} 
SANTOS, André Leonardo Copetti; LUCAS, Doglas Cesar. Por uma epistemologia dos vencidos: reposicionamentos teóricos para uma responsabilidade comum universal sobre as mobilidades humanas de massa. Revista Eletrônica Direito e Política, Programa de Pós-Graduação Stricto Sensu em Ciência Jurídica da UNIVALI, Itajaí, v.13, n.3, 30 quadrimestre de 2018. Disponível em: www.univali.br/direitoepolitica - ISSN 1980-7791

ARNAUD, André-Jean. Governar sem fronteiras. Entre globalização e pós-globalização. Rio de Janeiro: Lúmen Júris, 2007. Ver ainda, do mesmo autor, La gouvernanceglobale, une alternativeaudroitinternational? In: Revista de Direito Internacional e Econômico. n. 9, out./nov./dez. de 2004.

ARNAUD, André-Jean. 0 direito entre modernidade e globalização. Lições de filosofia do direito e do Estado. Tradução de Patrice Charles Wuillaume. Rio de Janeiro: Renovar, 1999.

AUGÉ, Marc. Por uma antropologia da mobilidade. Maceió: EDUFAL: UNESP, 2010.

BADIE, Bertrand. O Fim dos Territórios. Ensaios sobre a desordem internacional e sobre a utilidade social do respeito. Lisboa: Instituto Piaget, 1995.

BADIE, Bertrand. Um mundo sem soberania. Os Estados entre o artifício e a responsabilidade. Lisboa: Piaget, 2000, p. 17.

BAUMAN, Zygmunt. Vidas desperdiçadas. Rio de Janeiro: Jorge Zahar, 2005.

BAUMAN, Zygmunt. Modernidade líquida. Tradução de Plínio Dentzein. Rio de Janeiro: Jorge Zahar, 2001, p. 203.

BECK, Ulrich. Liberdade ou capitalismo. Tradução de Luiz Antônio Oliveira de Araújo. São Paulo: Unesp, 2003, p. 206.

BENHABIB, Seyla. Los derechos de los otros. Extranjeros, residentes y ciudadanos. Barcelona: Gedisa, 2005.

BOTERO, Giovani. On the Cause of the Greatness of Cities. Toronto: University of Toronto Press, 2012.

BREUILLY, John. Nacionalismo y Estado. Traducción de José Pomares. Barcelona: Pomares-Corredor, 1990.

BUTLER, Judith. Vida precaria: el poder del duelo y laviolencia. Buenos Aires :Paidós, 2006.

BUTLER, Judith.Quadros da Guerra. Quando a vida é passível de luto? Rio de Janeiro: Civilização Brasileira, 2015.

CARBONELL, Miguel. Los derechos en la era de la globalización. In: CARBONELL, Miguel; VÄZQUEZ, Rodolfo (Orgs.). Estado constitucional y globalización. México: Porrúa, 2003.

CARDUCCI, Michele. Por um direito constitucional altruísta. Porto Alegre: Livraria do Advogado, 2003.

CARVALHAIS, Isabel Estrada. Os desafios da cidadania pós-nacional. Porto: Edições Afrontamento, 2004.

CEPAL/NACIONES UNIDAS. Globalização e Desenvolvimento. 2002. Disponível em: http://www.eclac.cl/publicaciones/xml/9/10029/GlobalizacionPortuguesCap8.pdf 
SANTOS, André Leonardo Copetti; LUCAS, Doglas Cesar. Por uma epistemologia dos vencidos: reposicionamentos teóricos para uma responsabilidade comum universal sobre as mobilidades humanas de massa. Revista Eletrônica Direito e Política, Programa de Pós-Graduação Stricto Sensu em Ciência Jurídica da UNIVALI, Itajaí, v.13, n.3, 30 quadrimestre de 2018. Disponível em: www.univali.br/direitoepolitica - ISSN 1980-7791

CORTINA, Adela. Una ética transnacional de corresponsabilidad. In: SERRANO, Vicente (Editor). Ética y globalización. Cosmopolitismo, responsabilidad y diferencia en un mundo global. Madrid: Biblioteca Nueva, 2004.

CRUZ, Manuel. Responsabilidad en tiempos de globalización. In: SERRANO, Vicente (Editor). Ética y globalización. Cosmopolitismo, responsabilidad y diferencia en un mundo global. Madrid: Biblioteca Nueva, 2004.

DOMENACH, H.; PICOUET, M. Lasmigraciones. Córdoba, Argentina: Universidad Nacional de Córdoba, 1995.

ESTRADA, Isabel. De Westefália ao projecto pós-nacional. In: PUREZA, José Manuel (Org.). Para uma cultura da paz. Coimbra: Quarteto, 2001.

FALK, Richard. Uma matriz emergente de cidadania: complexa, desigual e fluida. In: BALDI, César Augusto (Org.). Direitos humanos na sociedade cosmopolita. Rio de Janeiro: Renovar, 2004.

FERRAJOLI, Luigi. Más allá de la soberanía y la ciudadanía: Un constitucionalismo global. In: CARBONELL, Miguel; VÁZQUEZ, Rodolfo (Orgs.). Estado constitucional y globalización. México: Porrúa, 2001, p. 313-324.

FREY, M. \& MAMMEY U.ImpactofMigration in theReceiving Countries: Germany. Geneva: IOM, 1996.

FRIEDBERG, Rachel M.; HUNT, Jennifer. Impact of Immigrants on Host Country Wages, Employment and Growth. The Journal of Economic Perspectives. Vol. 9, n. 2, Spring, 1995, pp. 23-44. Disponível em: http://www.jstor.org/discover/10.2307/2138165?uid=3737664\&uid =2134\&uid =2479440 343\&uid $=2 \&$ uid $=70 \&$ uid $=3 \&$ uid $=2479440333 \&$ uid $=60 \&$ sid $=21103583431163$.

GARCÍA, Eusébio Fernández. Dignidad humana y ciudadanía cosmopolita. Madrid: Dykinson, 2001.

GEARY, Patrick J. O mito das nações. A invenção do nacionalismo. Tradução de Fabio Pinto. São Paulo: Conrad, 2005, p. 23.

GELLNER, Ernest. Naciones y nacionalismo. Madrid: Alianza, 1988.

HABERMAS, Jürgen. A inclusão do outro. Estudos de teoria política. Tradução de George Sperber e Paulo AstorSoethe. São Paulo: Edições Loyola, 2002.

HABERMAS, Jürgen. Direito e democracia. v. II. Rio de Janeiro: Tempo Brasileiro, 1997.

HABERMAS, Jürgen. Inclusão: integrar ou incorporar? Sobre a relação entre nação, Estado de direito e democracia. Revista Novos Estudos Cebrap. n. 52. São Paulo, 1998.

HILY, M. As migrações contemporâneas: dos Estados e dos homens. In: Anais do Seminário Cultura e Intolerância, São Paulo, nov./2003.

INTERNATIONAL MIGRATION INSTITUTE (IMI). Towards a New Agenda for International Migration Research. Universityof Oxford, 2006. 
SANTOS, André Leonardo Copetti; LUCAS, Doglas Cesar. Por uma epistemologia dos vencidos: reposicionamentos teóricos para uma responsabilidade comum universal sobre as mobilidades humanas de massa. Revista Eletrônica Direito e Política, Programa de Pós-Graduação Stricto Sensu em Ciência Jurídica da UNIVALI, Itajaí, v.13, n.3, 30 quadrimestre de 2018. Disponível em: www.univali.br/direitoepolitica - ISSN 1980-7791

JONAS, Hans. O princípio responsabilidade. Ensaio de uma ética para a civilização tecnológica. Rio de Janeiro: Contraponto; Puc-Rio, 2006.

JULIOS-CAMPUZANO, Alfonso. Globalización ilustrada. Ciudadanía, derechos humanos y constitucionalismo. Madrid: Dykinson, 2003.

KYMLICKA, Will; STRAEHLE, Christine. Cosmopolitismo, Estado-nación y nacionalismo. Un análisis crítico de la literatura reciente. México: Universidad Nacional Autônoma de México, 2001.

LEVINAS, Emmanuel. Alterity and transcendence. New York, Columbia University Press, 1999.

MAGUID, Alicia. Migrantes limítrofes enla Argentina: suinserción e impacto enel mercado de trabajo. EstudiosdelTrabajo, N 10, Buenos Aires, ASET, 1995.

MALTHUS, Thomas. An Essay on the Principle of Population. Adelaide: The University of Adelaide Libray. Disponível em: http://ebooks.adelaide.edu.au/m/malthus/thomas/m26p/index.html. Acesso em: 20 jun. 2014.

MÁRMORA. Lelio. Las políticas de migracionesinternacionales. Buenos Aires, Paidós, 2002.

MARTIN, Frey; MAMMEY, Ulrich; KOSINSKI, Leszek A. Impact of migration in the receiving countries: Germany. Geneva: InternationalOrganization for Migration, 1996.

MARTINE, G. Globalização inacabada: Migrações internacionais e pobreza no século 21. São Paulo em Perspectiva. V.19, n.3, jul/set., 2005, pp. 3-22.

MARTINEZ, José Maria Seco e PRIETO, Rafael Rodriguéz. Espacios y ritmos para una nueva concepción de la ciudadanía. In: JULIOS-CAMPUZANO, Alfonso (Editor). Ciudadanía y derecho en la era de la globalización. Madrid: Dykinson, 2007, p. 327341.

MENDÉZ, Manuel Toscano. Ciudadanía, nacionalismo y derechos humanos. In: CARRACEDO, José Rubio; et al. Ciudadanía, nacionalismo y derechos humanos. Madrid: Trotta, 2000.

MENDÉZ, Manuel Toscano. Nacionalismo y pluralismo cultural. Algunas consideraciones. In: CARRACEDO, José Rubio; et al. Ciudadanía, nacionalismo y derechos humanos. Madrid: Trotta, 2000.

MONTESQUIEU. O Espírito das Leis. São Paulo, Martins Fontes, 1996, p. 458.

PATARRA, N.L. Migrações Internacionais de e para o Brasil Contemporâneo.São Paulo em Perspectiva. V.19, n.3, jul/set. 2005, pp. 23-33.

PATARRA, N.L. Migrações Internacionais: Teoria, políticas e movimentos sociais. Estudos Avançados, v.20, n.57, 2006, pp. 7-24.

PLATÃO. A República. 8. ed. Lisboa: Fundação CalousteGulbenkian, 1996. 
SANTOS, André Leonardo Copetti; LUCAS, Doglas Cesar. Por uma epistemologia dos vencidos: reposicionamentos teóricos para uma responsabilidade comum universal sobre as mobilidades humanas de massa. Revista Eletrônica Direito e Política, Programa de Pós-Graduação Stricto Sensu em Ciência Jurídica da UNIVALI, Itajaí, v.13, n.3, 30 quadrimestre de 2018. Disponível em: www.univali.br/direitoepolitica - ISSN 1980-7791

PUREZA, José Manuel. El patrimonio común de la humanidad. ¿Hacia um derecho internacional de la solidariedad? Madrid: Trotta, 2002.

ROSENAU, James. A cidadania em uma ordem mundial de mutação. In: ROSENAU, James; CZEMPIELL, Ernest-Otto (Orgs.). Governança mundial sem governo. Ordem e transformação na política mundial. Tradução de Sérgio Bath. Brasília: UnB, 2000.

SANTOS, André Leonardo Copetti. A Repressão das Diásporas em Tempos Globais e os Direitos Humanos dos Migrantes. In: BEDIN, Gilmar (Org.). Cidadania, Direitos Humanos e Equidade. Ijuí: Editora UNIJUÍ, 2012, pp. 339-374.

SMITH, James P.; BARRY, Edmonston. The Immigration Debate: Studies on the Economic, Demographic and Fiscal Effects of Immigration. Washington D.C: National Academy Press, 1998.

STALKER, Peter. No-Nonsense Guide to International Migration. Oxford: New Internationalist Publications, 2001.

STALKER, Peter. Workers without Frontiers. London: Lynne Rienner Publishers, 2000.

TIVEY, Leonard. EI Estado nación. Tradução de Marco-AurelioGalmarini. Barcelona: Península, 1987.

VEJO, Tomás Pérez. Nación, identidad nacional y outros mitos nacionalistas. Oviedo: Nobel, 1999.

VIEIRA, Liszt. Cidadania e globalização. Rio de Janeiro: Record, 1997.

Recebido em: 21/11/2018

Aprovado em: 05/12/2018 